\title{
جماليات المفارقة وتشظيات النص القصة العراقية القصيرة اثموذجة
}

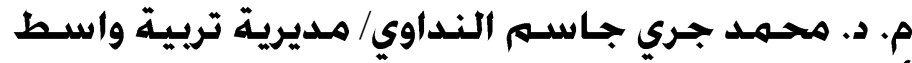

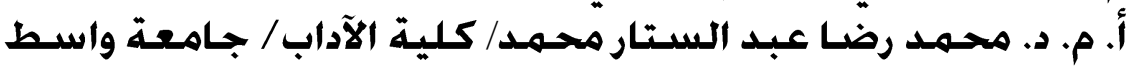

هدظل:

دأبت الدر اسات النقدية و البلاغية التي تتناولت موضوع المفارقة في تعاطيها مع النصوص الأدبية تحليلاً وتنظبراً،

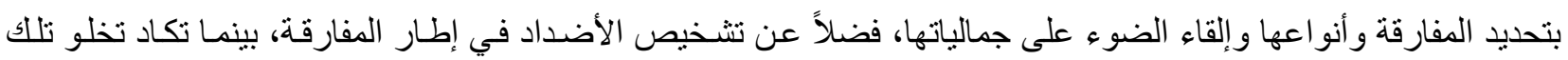

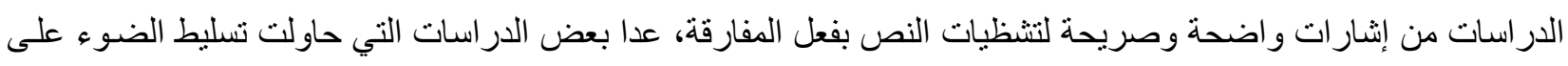

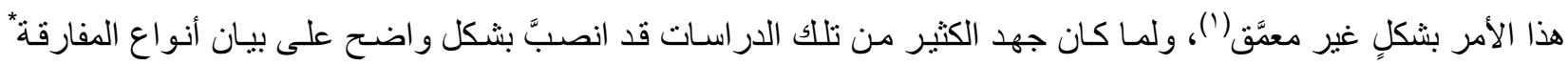

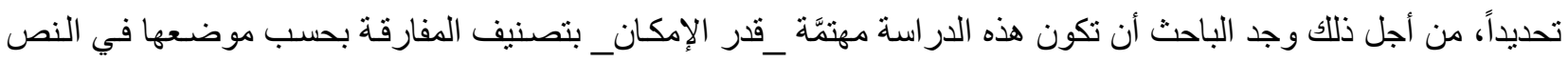

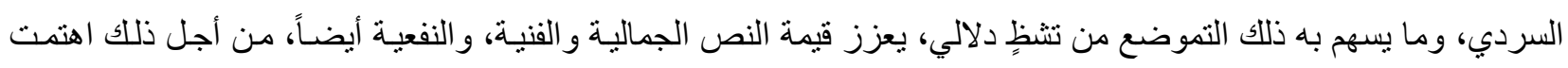

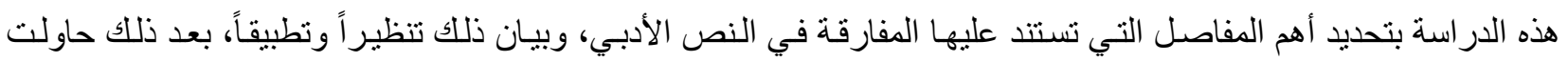
تصنيف المفارقة بحسب موضعها في النص إلى: (مفارقة نهاية، ومفارقة نصية، ومفارقة بداية، ومفارقة عنوان) وكما سيتم

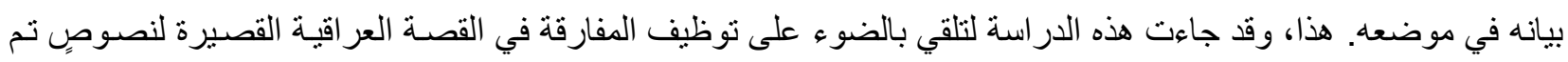

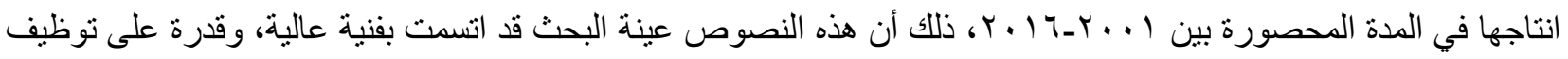

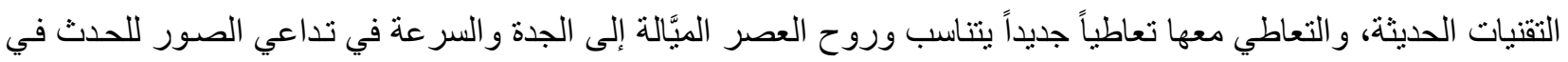

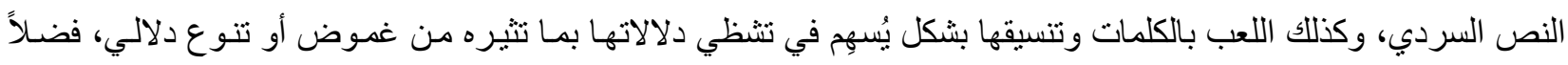

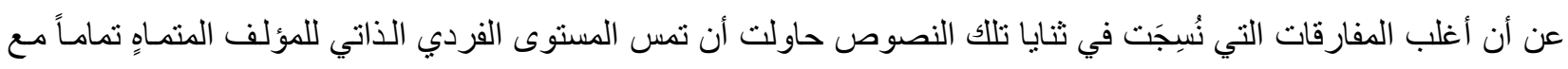
الو عي الجمعي للمجتمع الذي يحيا فيه، ويتعاطى معه تأثر اً وتأثير اً.

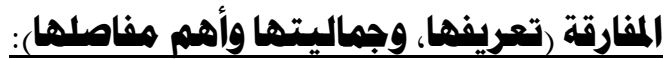

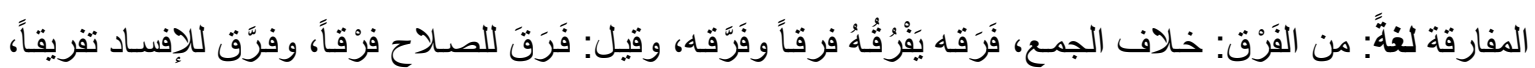

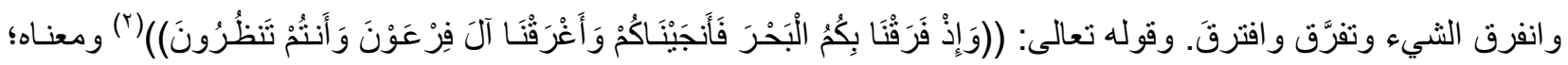

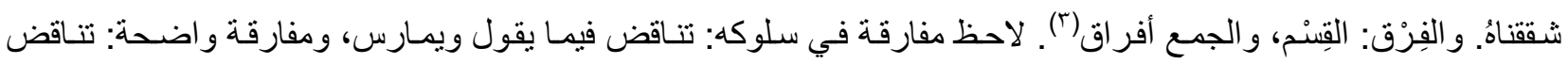

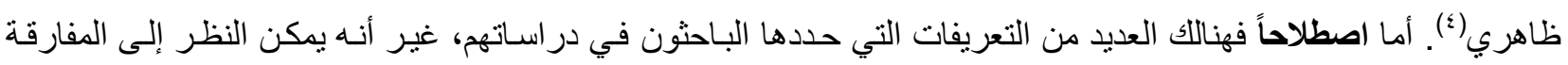

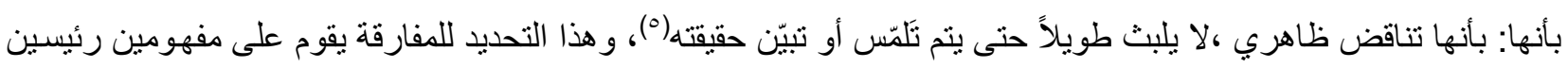

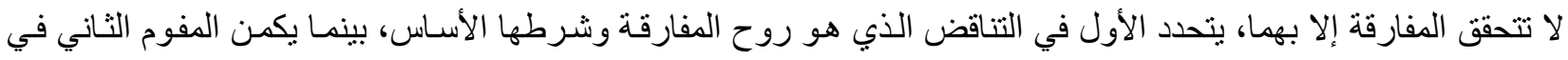

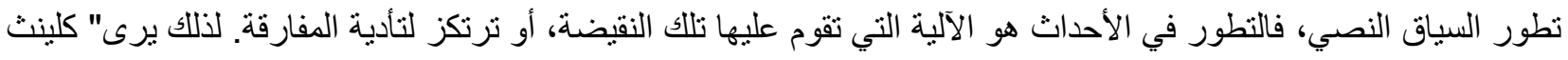

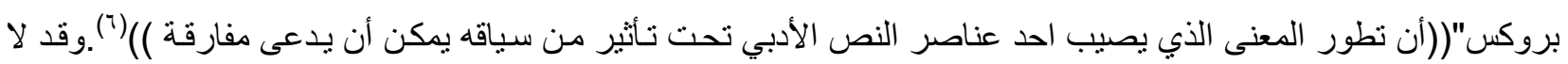
يكون المقصود بالتطور للمعنى أو الحدث نموهو اتضاحه، بقدر ما يكون المقصود من ذللك هو تحول المعنى من سياقه إلى الى

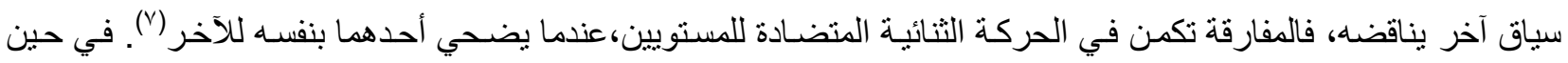

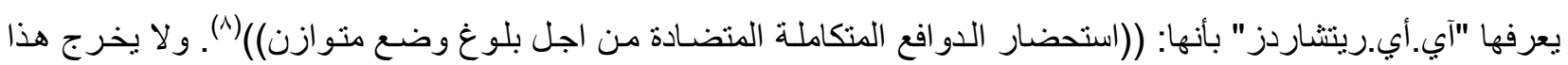
التعريف عن حدود المفهومين السابقين في تحديد فحوى المفارفة، غير أنها وقبل أن تُحدد هذا التحديد، مرت بـت بتأريخ زمني طويل غني بالمفاهيم و المعاني حتى اكتسبت هويتها وتعريفها أو كينونتها المتسعة التي لا يمكن حصر ها عند حد، حتى أنها قد الد

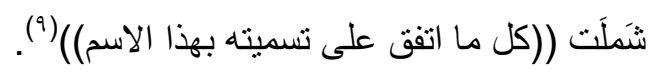


تتحدد للمفارقة جمالية واضحة، كونها فنـاً يُنسَج بقصدية ملموسـة، وبإتقان من أجل الإشـارة و التلميح، لا الإفصـاح

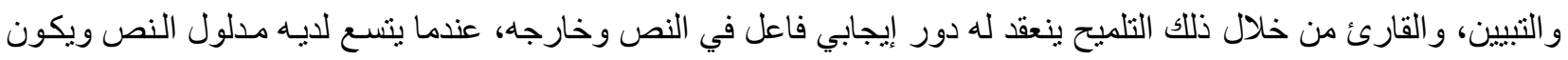

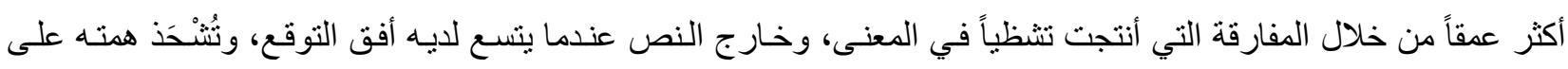

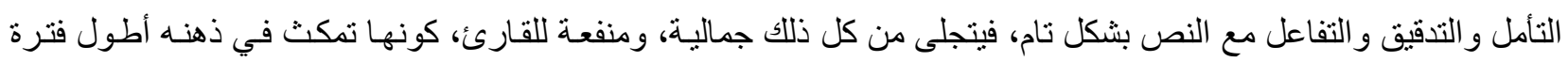

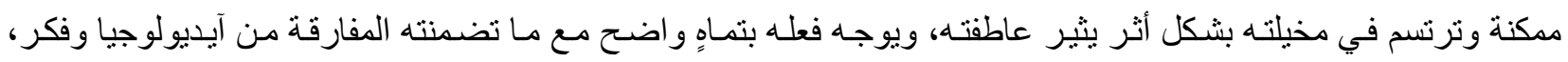

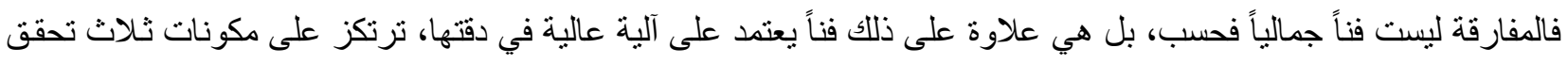

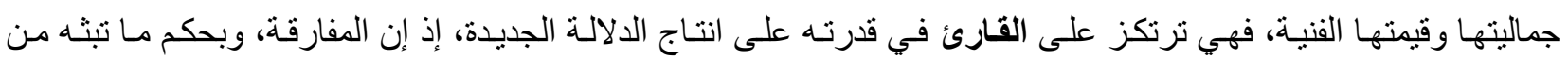

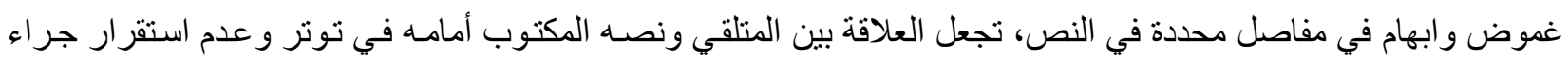

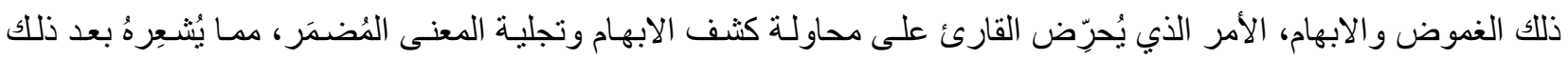

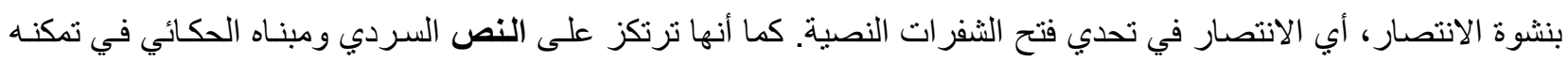

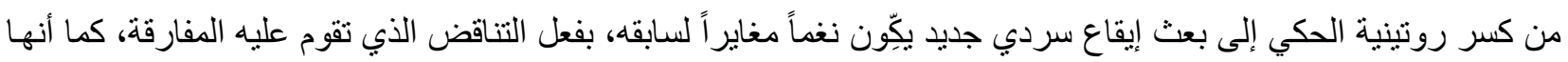

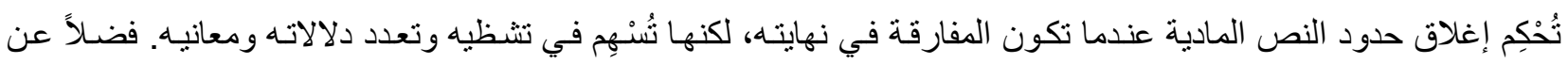

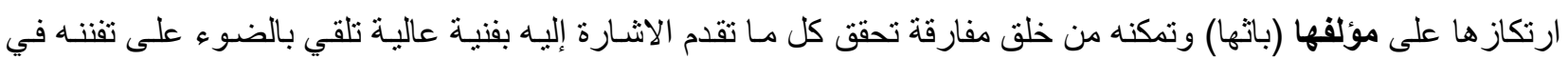

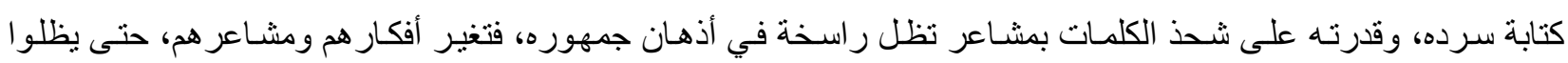
مشغولين بها تماماً.

تعتمد المفارقة أيضاً على مفصلين رئيسين يحددان وجودها ويدعمان فنيتها، بما يشكل جماليتها وتشظيها، أولهمـا:

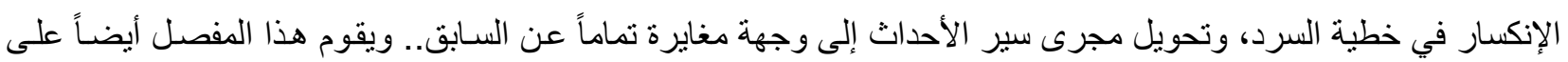

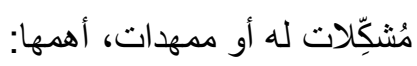

ا. تقديم معلومات عامة عن الثخصيات أو الأحداث الرئيسة أو الفضـاء السردي، دون الدخول في التفاصيل التي تثير

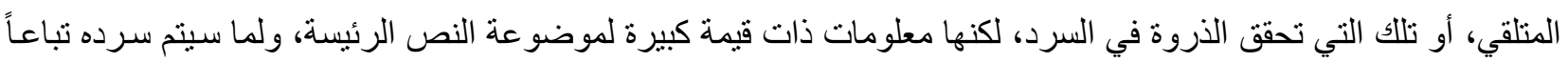

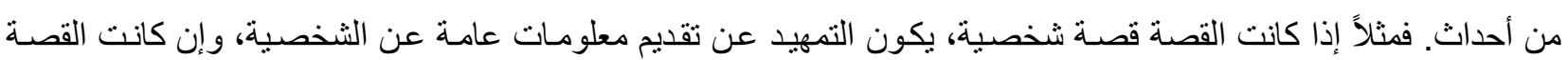
قصة فضاء سردي، يكون التمهيد عن الفضاء الذي ستدور الأحداث فيه.

r. التأني في تقديم تلاك المعلومات أو في سرد الأحداث ورو ايتها، لحين بث المعلومات على شكل دفقات رتيبة سلسـة وبطيئة.

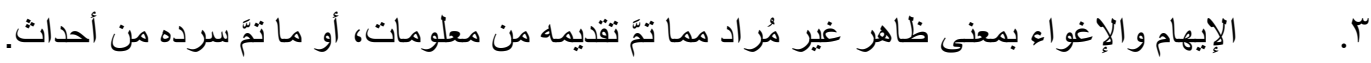
وثانيهما: التشظي الدلالي الذي يعتمد هو الآخر على ركيزتين اساسيتين، هما: l. نقض المعنى السابق الظاهر ونسفه، وتثييد معنى جديد يعتمد على رفاته.

r. الثبات و الترسيخ: ويقوم على تحقيق الثبات للمعنى الجديد و التلويح بترسيخه في السرد من خـلال بعض التلميحات

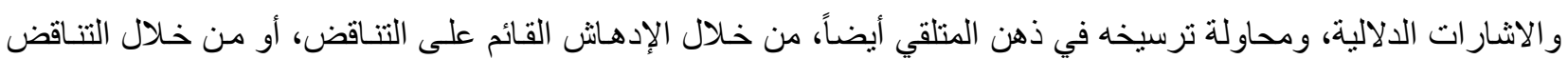
الذي هو روح المفارقة وجوهر ها.

من ذلك يمكن القول أن المفارقة ليست بنية مستقلة عن النص، بل هي مفصل متلاحم وشديد التلاحم به، كمـا أنه يُؤسَسُ لـه منذ

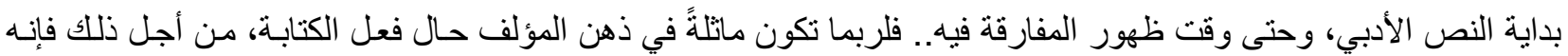


يَعَد إلى توجيه المبنى الحكائي للنص نحو وجهة محددة، لتكون خاتمته مفارقة تشحن النص بدلالات عديدة، أو محددة، وبذللك

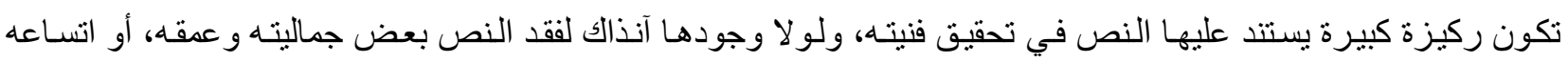

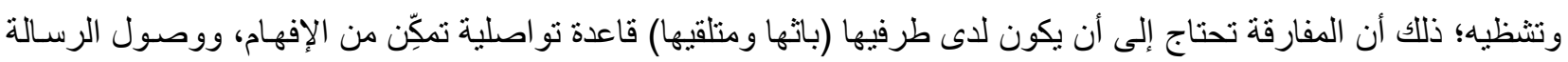

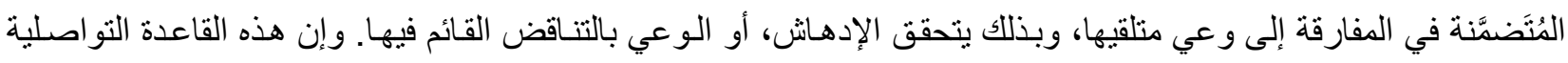

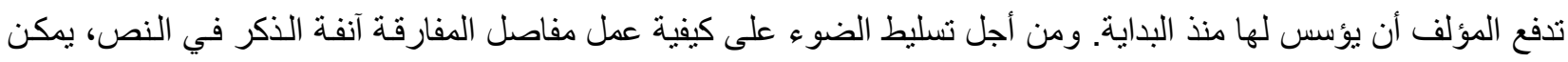

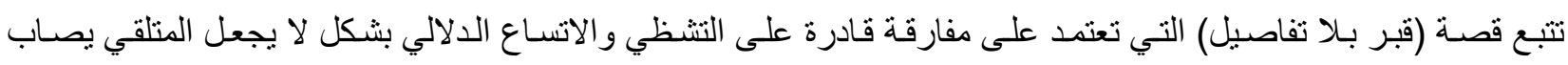

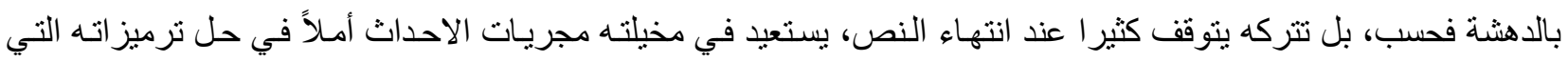

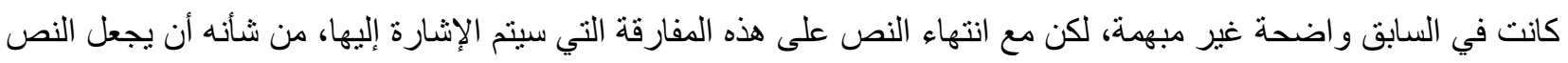

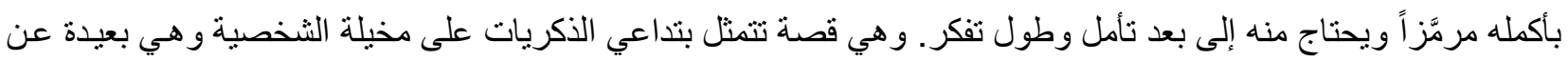

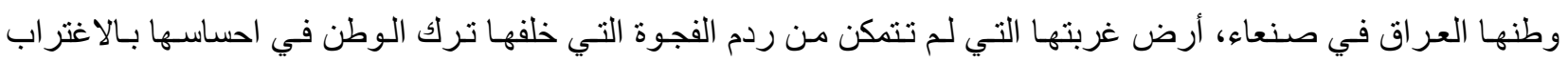
والتشظي و التشتت، تظل الثخصية عائمة في ماضيها الذي لا يزال ماكثاً في روحها، إلى درجة غيابها عن الواقع الآني تماماً، وهي في غرفة الصف أمام طلابها، أو على مائدة الطعام في أحد مطاعم صنعاء مع صديقها الذي تحرف مسار مسار الحديث معهـ عن المقابر والأموات، لتسر إليه رغبتها في أن ثُفَنَ في صنعاء بقبر بلا تفاصيل كثثبر عنها، فقط شاهد لقبر يحمل اسمها. لتأتي

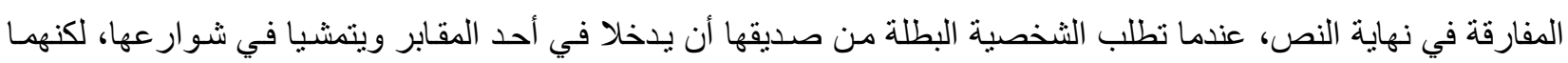

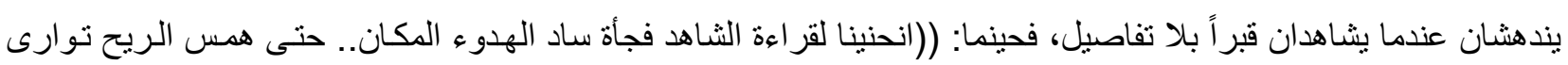

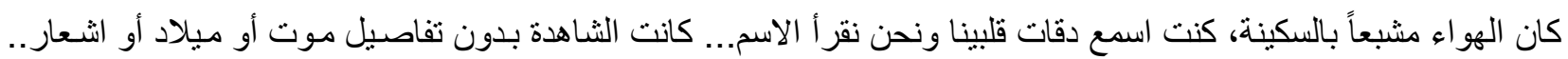

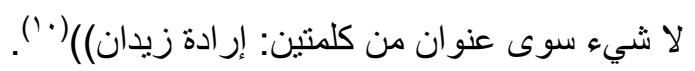

هذه الخاتمة للنص تتضمن مفارقة تستفز القارئ لمر اجعة كل ما طُبحَ في ذهنه عن النص و عن الثخصية، هل أن مـا

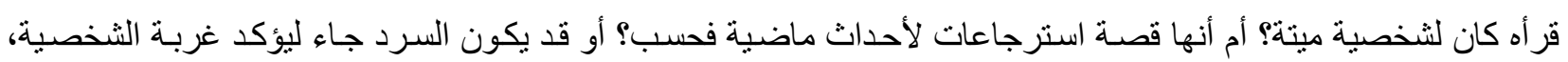
و أنها مدفونة حقاً في بلاد غربتها في صنعاء/مقبرتها التي هي في نظرها بلا تفاصيل، وبلا ملامح، وبلا طعم؛ لأن طعم الوطن

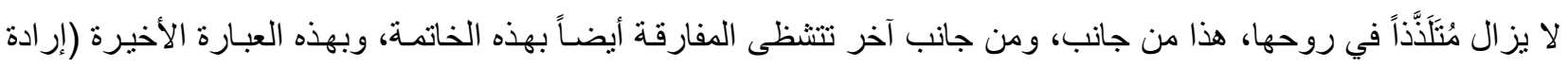

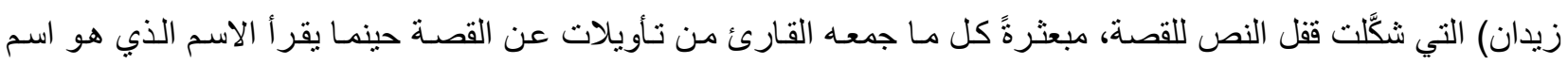
المؤلفة (إر ادة زيدان الجبوري) المغتربة عن بلدها العراق في صنعاء. إن هذه المفارقة التي حددت المساحة الماديـة للقصـة عملت على تشظي دلالات النص بشكل كبير عزز جماليته المتحققة بالضبابية وعدم الإفصـاح أو المبانشرة في كثف فئ معنى النص، عندما جاءت العبارة الأخيرة في خاتمنه على مفارقة جعلت منه نصاً مفتوحاً على تأويلات متعددة. أما قصة (أشباح الوطن) فيتضح فيها بجلاء، كيفية التأسيس للمفارقة بالشكل الذي أسلفنا ذكره، وهي قصـة تتحصور

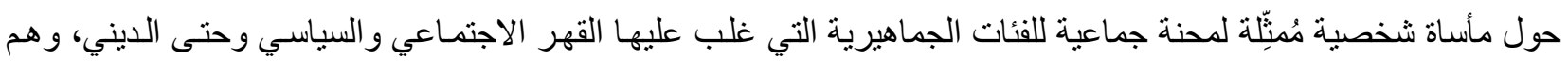
الأقلية المسيحية العر اقية التي عانت من الاضطهاد و التهجير القسري في حقب زمنيـة محددة، لاسيما بعد الاجتياح الامريكي للعر اق، وتصاعد تيار ات الفتنة الطائفية..

تبرز أولى ملامسح أزمـة الثخصية عند احساسها بالتلاشـي والاستلاب إلى درجة أن الثخصية لا تتمكن من النوم؛

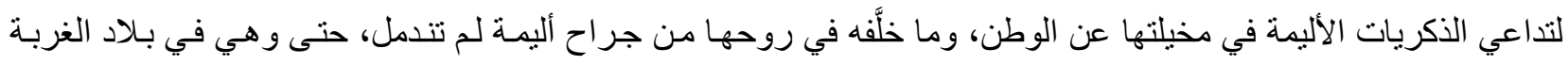

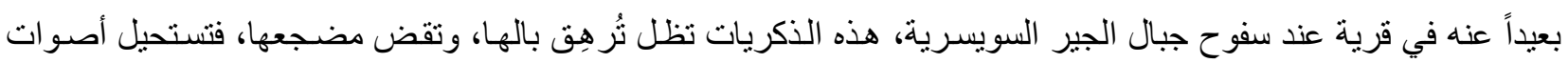

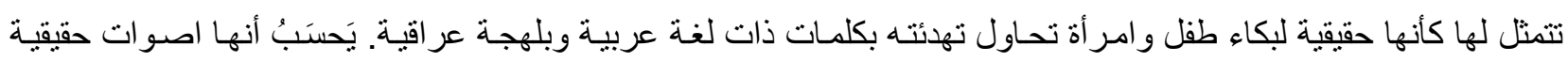


لجير انه الملاصقين لدار صديقته ماريان التي طلبت منه البقاء فيها حال عودتها من زيارة اهلها، مما يدفعه في اليوم التالي الى الى

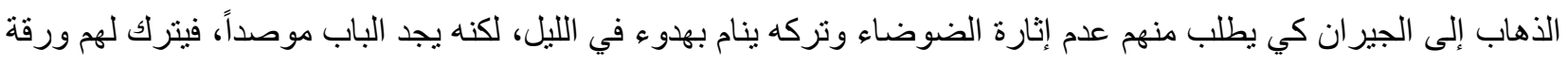

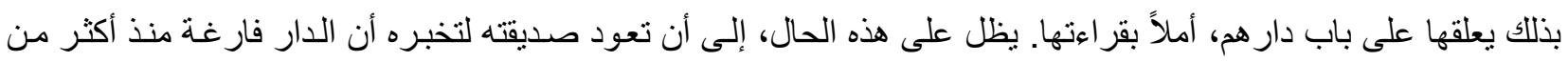
شهرين..

المفارقة تتحور حول انكثاف تأزم الثخصية ومحنتها تجاه وطنها، وكذللك رغبتها في الابتعاد عن كل الذكريات

الأليمة التي عصفت ببلادها وبها أيضاً، غير أنها لم تفلح أبداً في ذلك: ((كم عانيت من إنهيار آخر أحلامي في هذا الوطن [...]

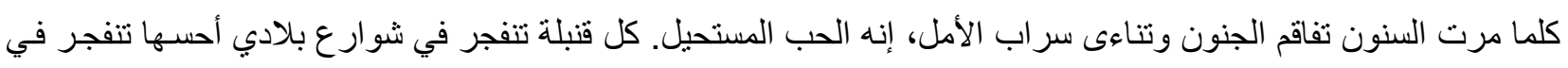

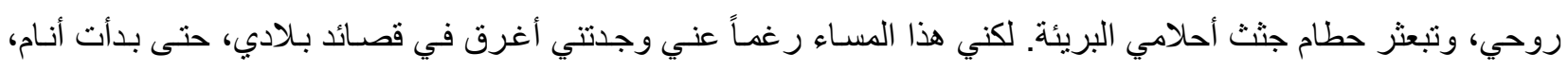

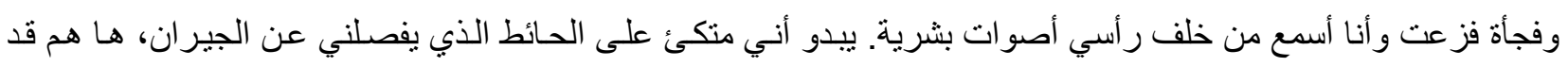

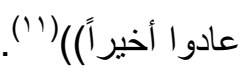

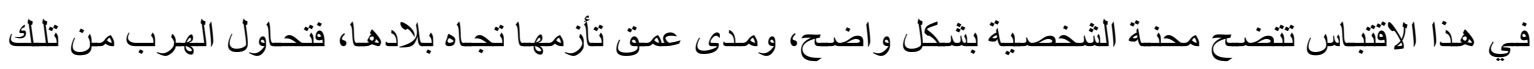

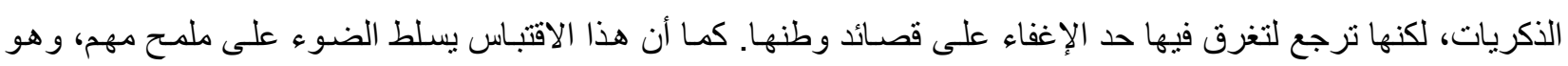
محاول التأسيس منذ البداية للمفارقة التي سينتهي عندها المنن الحكائي للنص، وذللك عندما يحاول الكاتب خداع المتلقي بحقيقة الاصو ات التي تسمعها الثخصية: ((وفجأة فزعت و أنا أسمع من خلف رأسي أصوات بشرية. يبدو أني متكئ على الحائط الذي وني

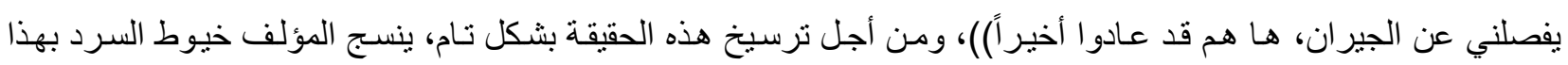

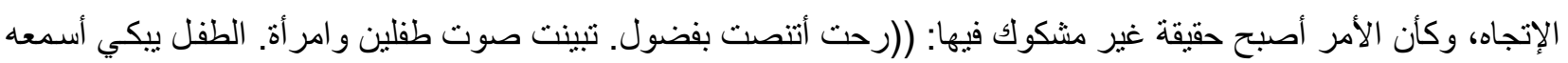

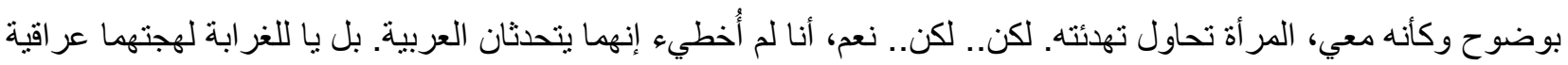

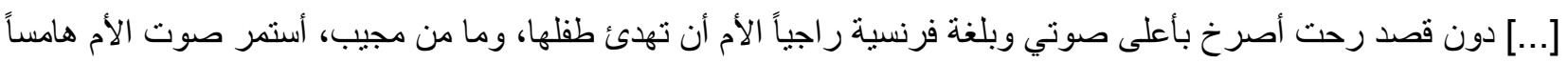

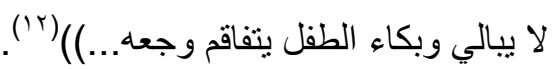
يظل على هذه الحال، لتصير حقيقة وجود الطفل و أمه لا ريب فيها، عندئذ يأتي دور إنكثـاف المفارقة، كي تؤسس لتتظي الدلالات وتعميق ثيمة النص، حينما تأخذه ماريان الى البيت ليكتثف خو اءها: ((نعم ويـا للعجب! الباب أساسـاً لم يكن

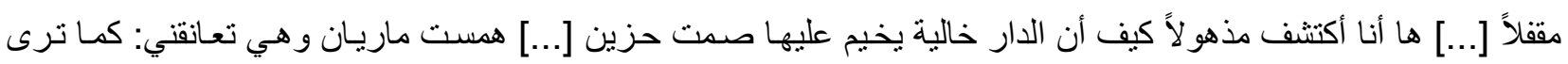

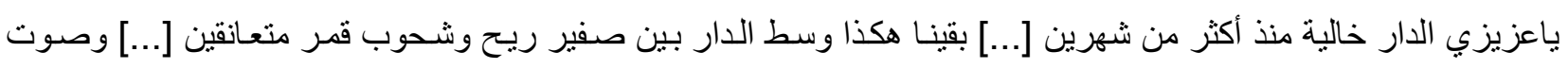

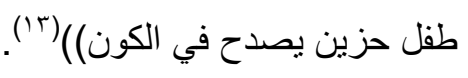

من خلال هذين النموذجين، حاول الباحث تسليط الضوء على أهم آليات تشكُل المفارقة ومفاصل تكوُنها تطبيقاً، بعد أن

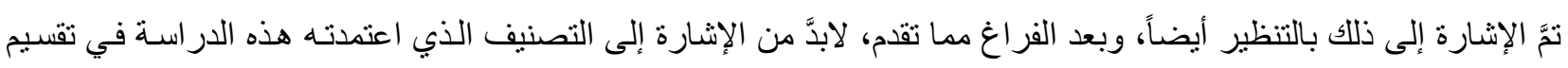

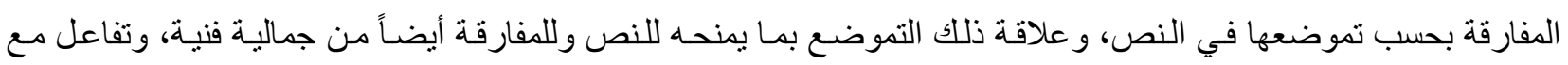

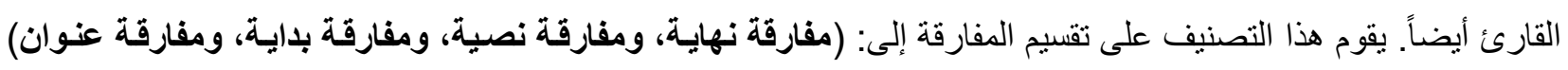
وكما سيتم بيانه تباعاً.

أولآ: هفارقة نهاية:

لم يكُن اهتمام النقاد و الأدباء منصباً على المطالع و البدايات فقط، من غير أن تكون للنهايات نصيياً من عنايتهم، فهي

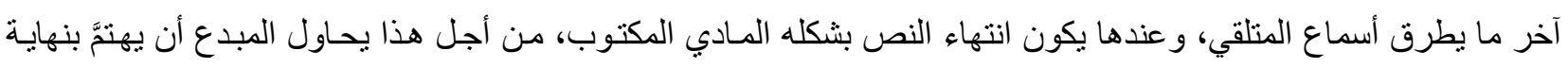

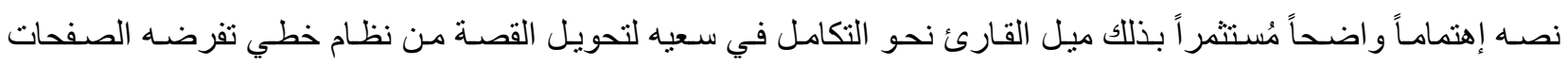


المطبو عة إلى وحدة ذهنية تامة مؤطَّرة ومحدّدة، وبر غبة جامحة ومتو اصلة لتحقيق الاستيعاب التام لتلك القطعة النترية، وهذه

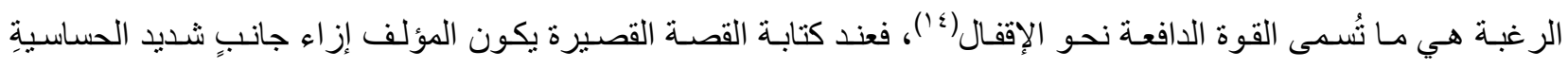
و الأهمية بجسد القصة ككل، ويقعُ عليهِ المُعوّل في كثف فيوضات النص الآيديولوجية والأخلاقية و العاطفية وصقلها وتحديدها،

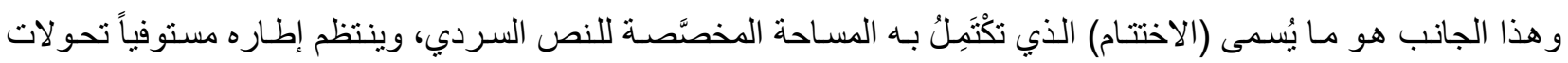
وحداته الحكائية والمعرفية والثيمية. غير أنه يتخذ شكلين متميزين ينبغي ضرورة الإشارة إليهما: يتحدد الأول في اختتام حكايـة

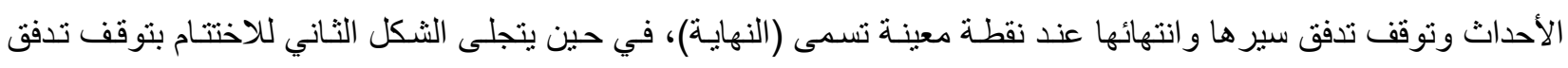

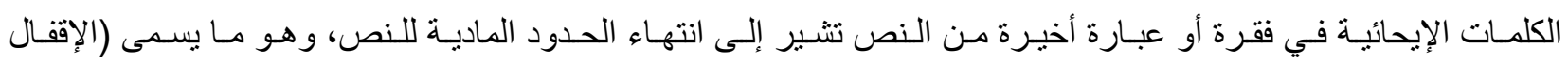

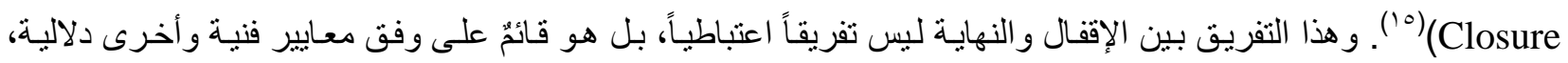

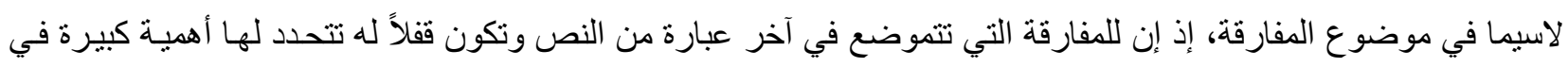

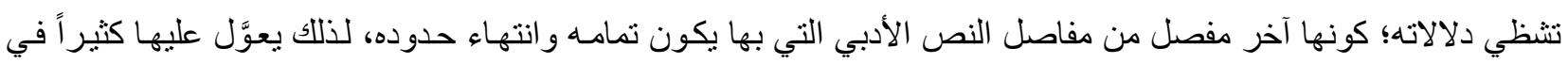

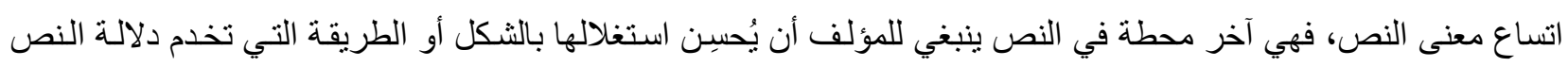

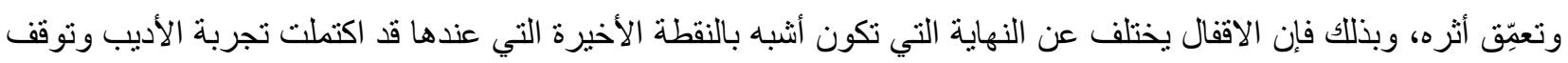
عندها احساسه باكتمال تمثيله لتجربته الفنية التي قد احدثت عنده التوتر قبل قيامه بفعل الكتابة، بينما الإقفال هو آخر عبارة منها

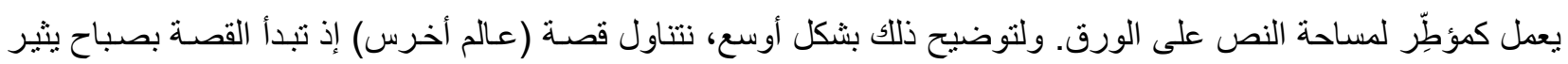

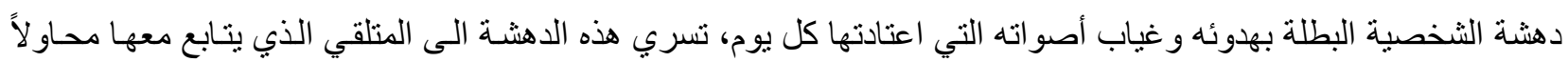

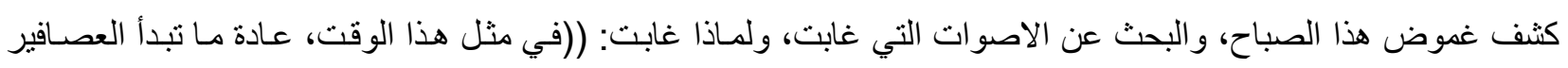

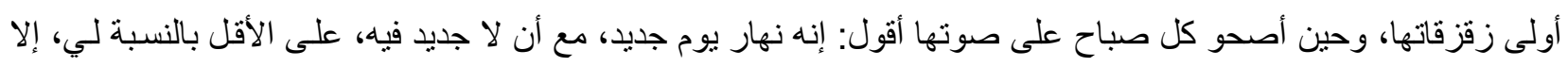
أن أمراً غريباً حدث هذا الصباح خلخل عالمي، إذ إنني لم أسمع خفق أجنحتها ولا تغريدها، كما لو أنها رحلت إلى الأبد [...]

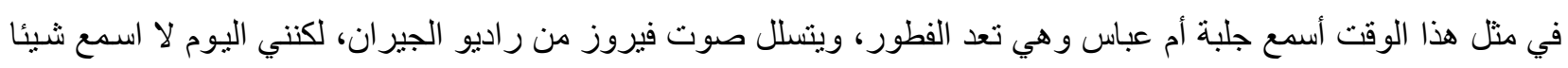

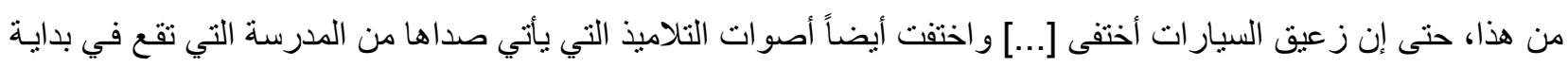

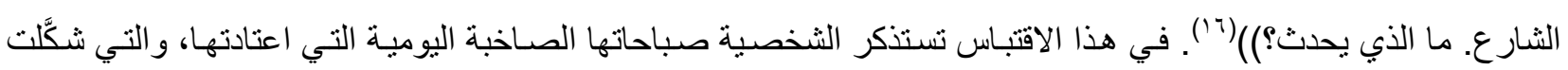

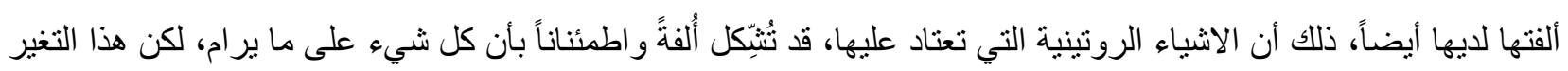

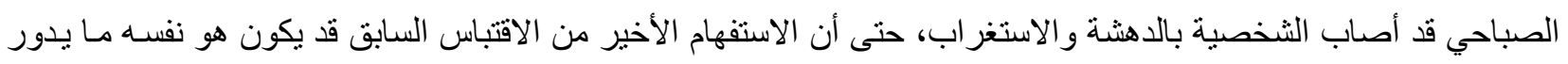

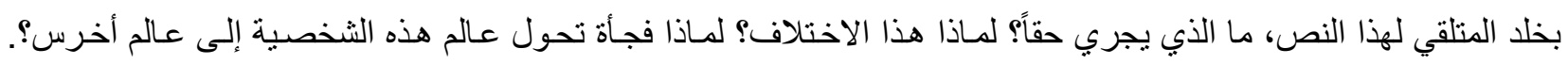
يزول ذلك الغموض شيئاً فثيئاً، حينما يتلقى القارئ وهو يتابع سرد القصـة، أن الثخصية قد نعرضت للصمم، بسبب قذيفة

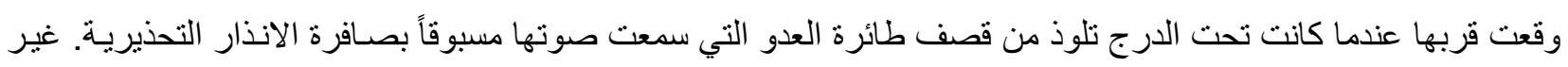

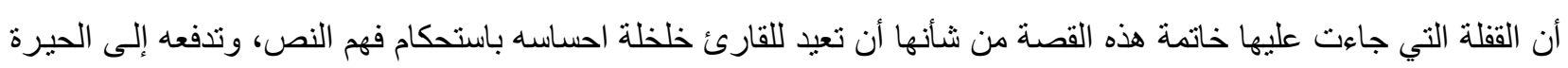

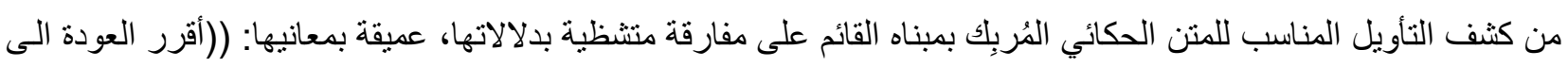

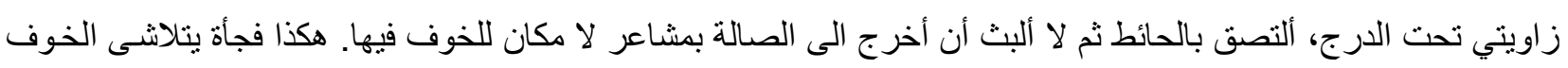

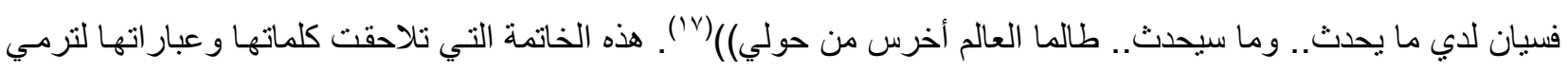

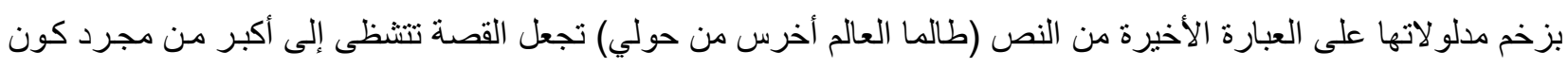

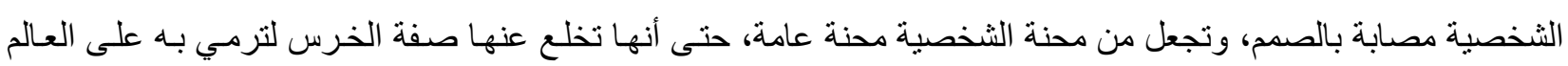

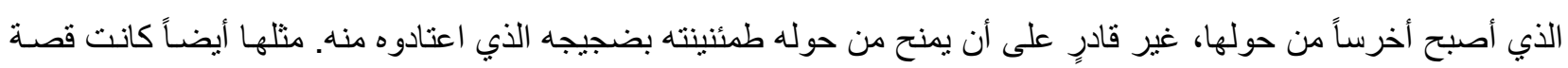

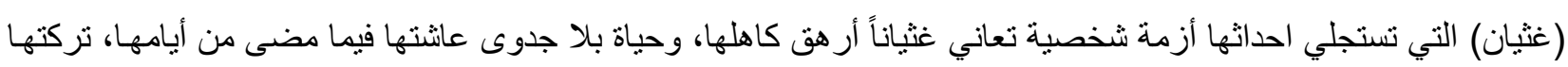


تعيش إنكسار ها مر اراً حتى قل إحساسها بالخارج، فباتت الأصوات من حولها مشوشـة، و الوجوه شـاحبة مسلوبة، كل ذلك يتت تلقيه من خلال عيني الثخصية البطلة التي تتحرك أمام عيني القارئ وضمن عالمها السردي المتخيل بكل سهولة و عفوية، غير التهات

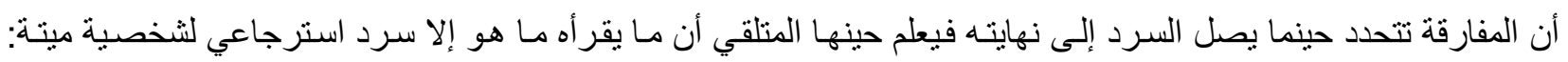

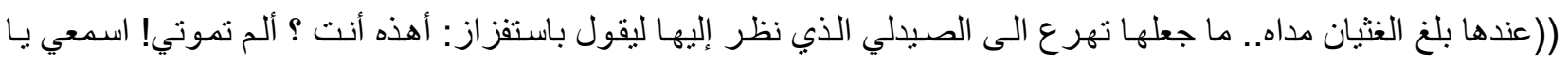

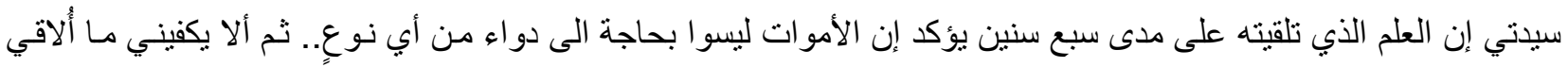

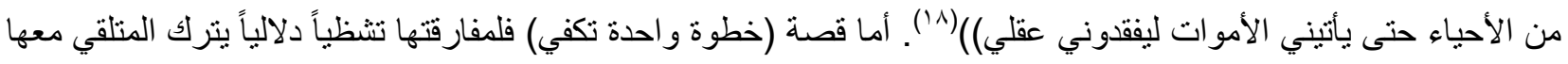

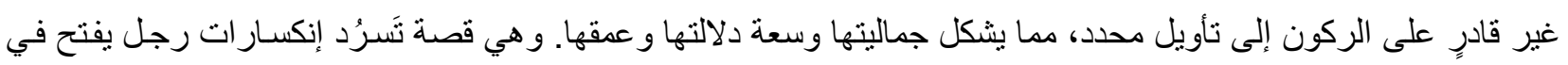

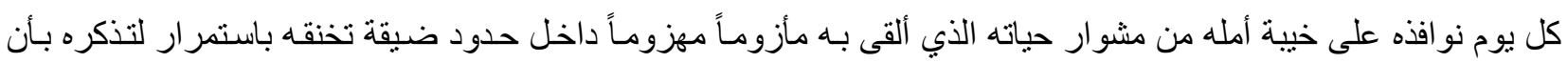

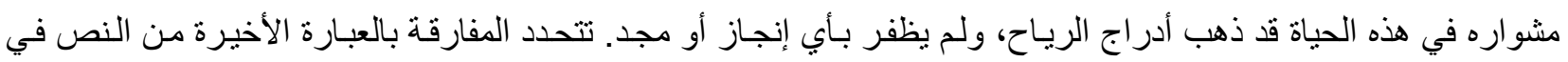

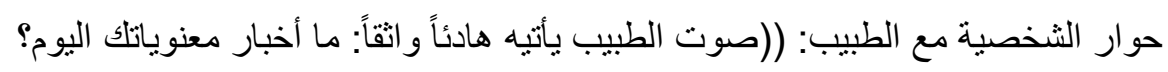

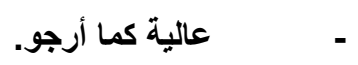

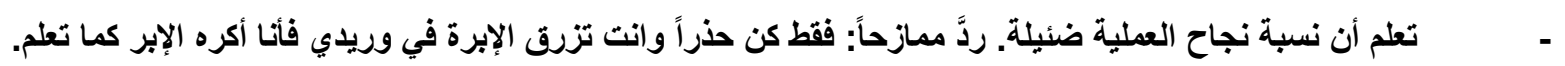

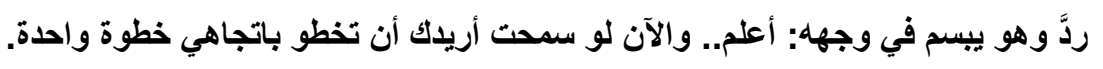
خطوة واحدة تكفي.)(19). هذه العبارة الأخيرة (خطوة واحدة تكفي) على الرغم من وجازتها إلا إنها تحرف مسار

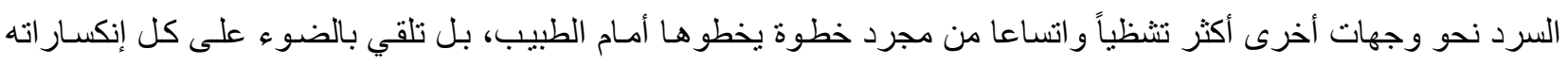

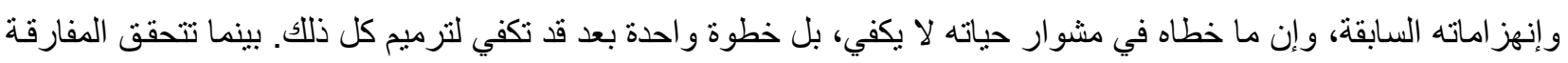

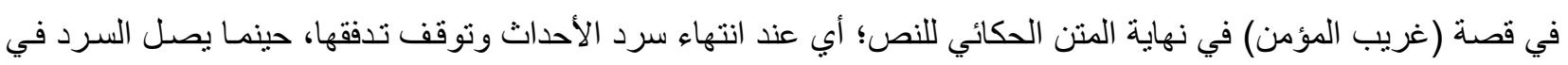

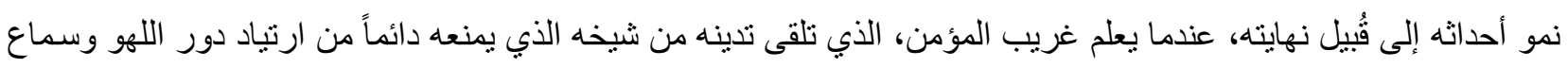

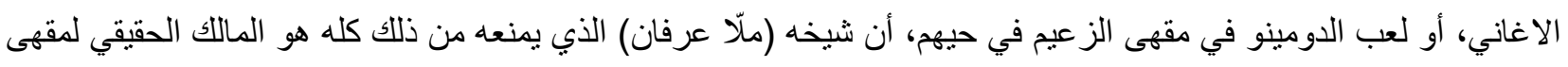

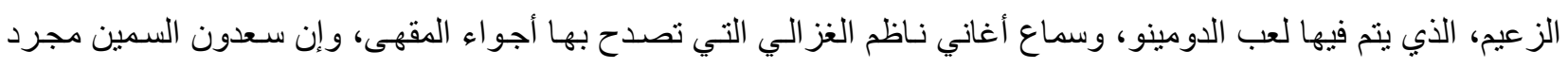

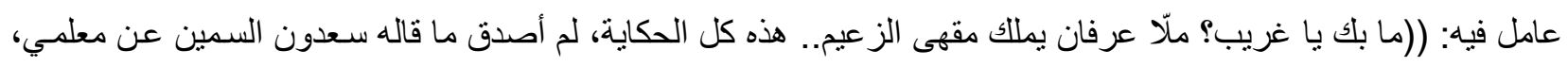

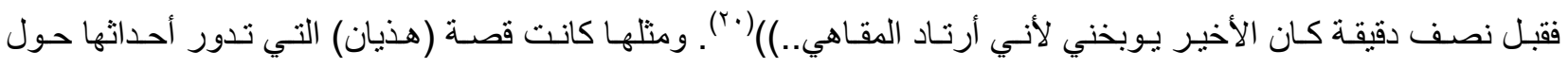

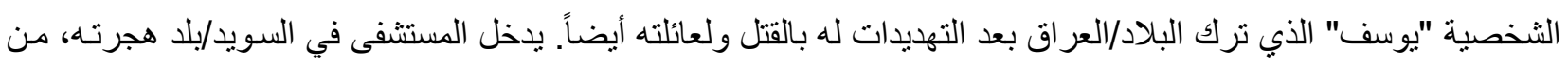

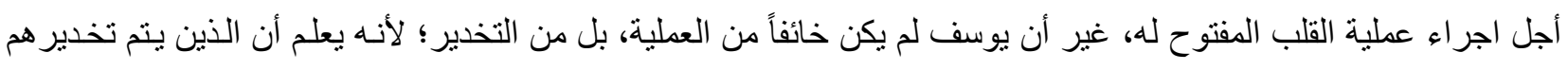

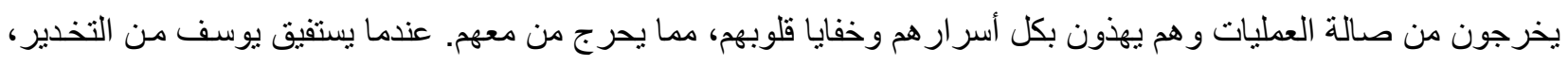

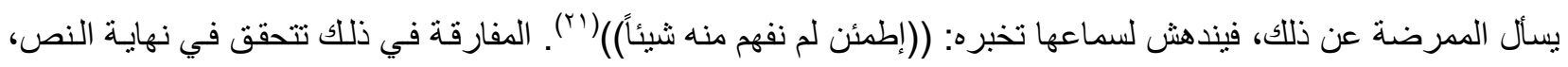

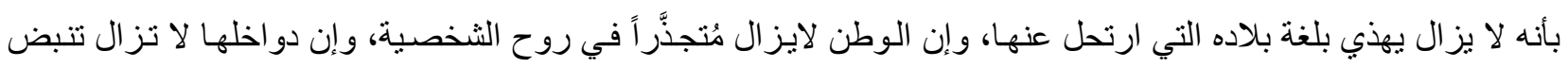

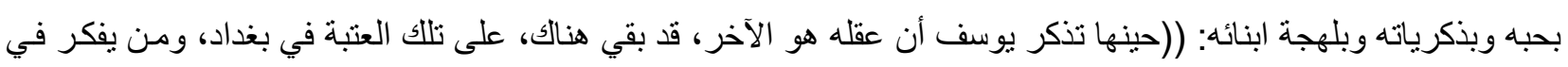

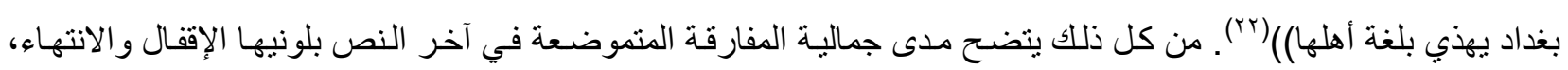
ومدى قدرتها على التشظي الدلالي في الوقت الذي يكاد أن ينتهي به السرد تماماً.

\section{ثانياً: هفارقة نصية:}

للنص السردي كيان مادي فيزيائي متكون من كلمات مطبو عة على الورق، و هذا الكيان تتفاعل فيه وتتداخل جملـة من

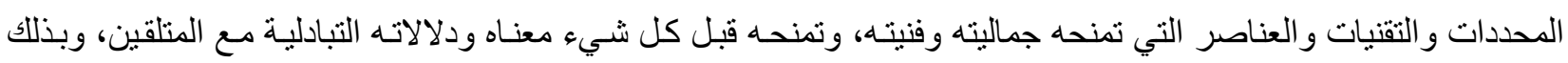

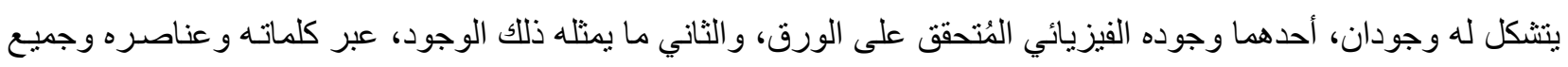


مفاصله، من دلالة عند المتلقي. بمعنى آخر ؛ إن للنص السردي (مبنى حكائي، ومنن حكائي)، فالمبنى الحكائي هو بناء نصي

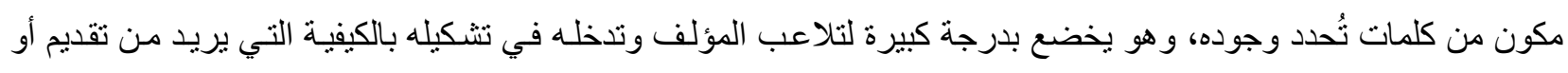

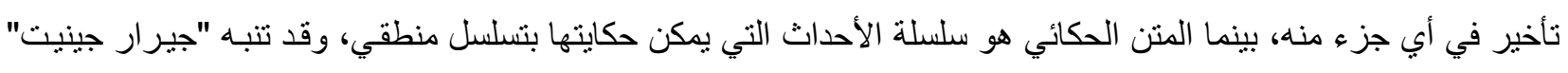

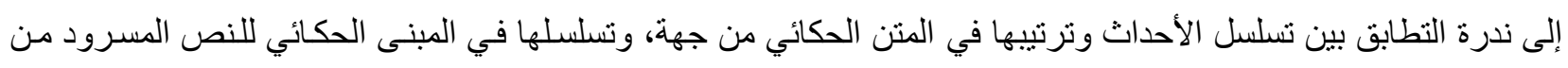

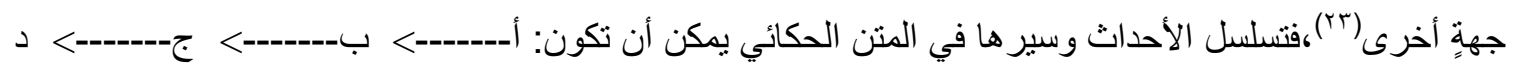

أما في المبنى الحكائي الخاضـع لتدخل الكاتب وتلاعبه بـه فقد لا يكون بالتسلسل السـابق نفسـه، بـل قد يُعتَمد التقديم

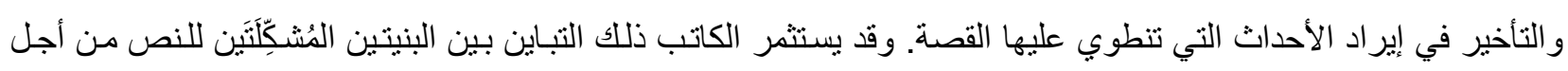

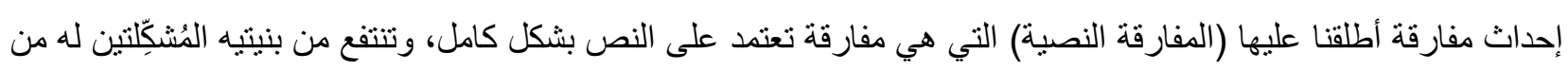

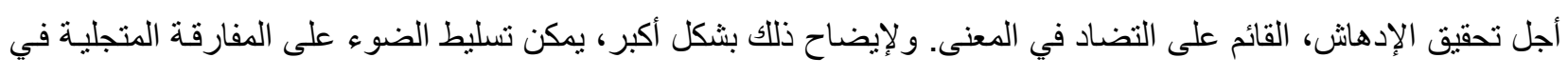

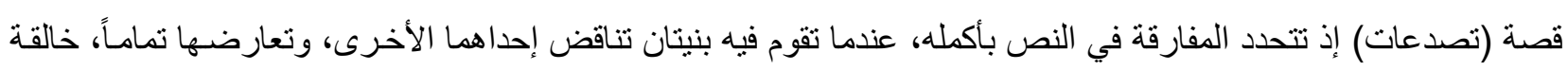

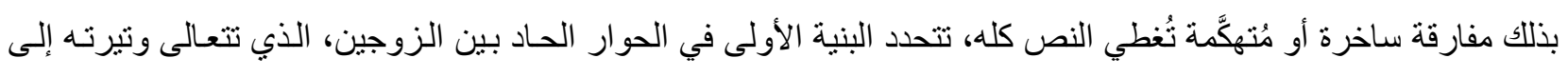

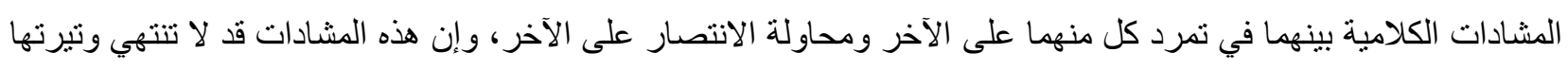

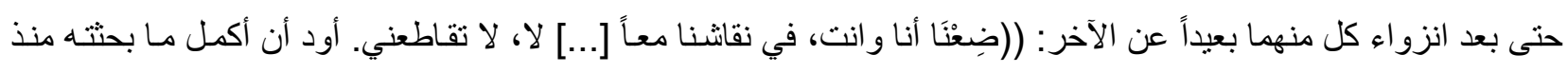

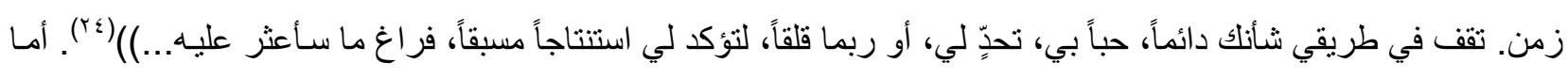

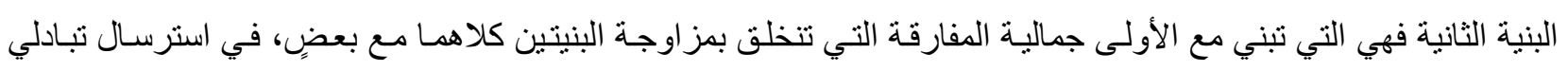

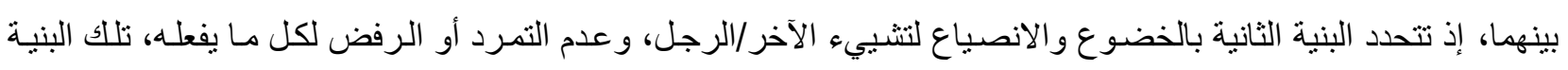

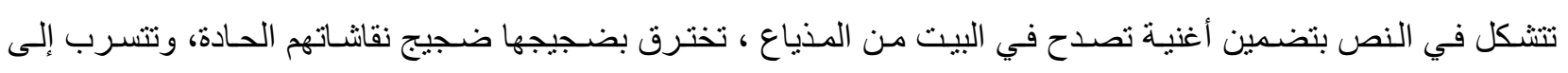

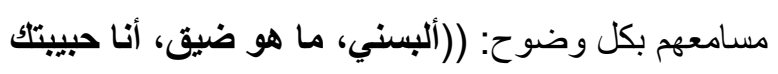

لعبتك

لا، لا تقاطعني. أود أن أكمل [...]

حركني، انطقني

إفعل مايرضيك

أقول دعك بالله محور أول- لنكمل ما بدأناه. ستحرق روحك إن أصغيت لذات غير ذاتك [...]

\section{قبلني هنا، إلمسني هناكت... هانكي يانكي}

بإمكاتك اللمس، اللعب...)(ro(r). تستمر هاتان البنيتان في تضـاد يخلق مفارفة ترتمي بإطار فها في كل ثنايا النص،

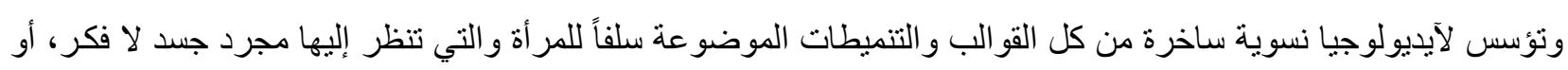

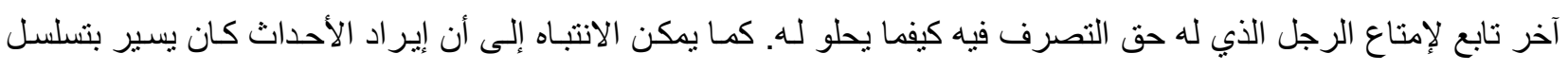

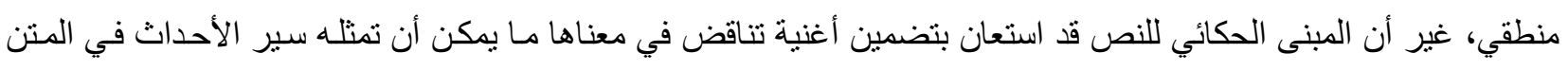

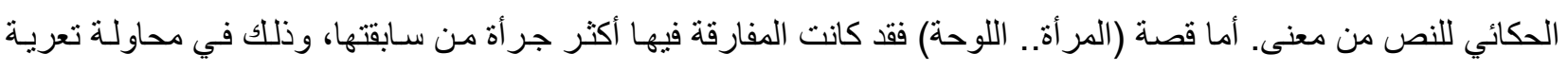

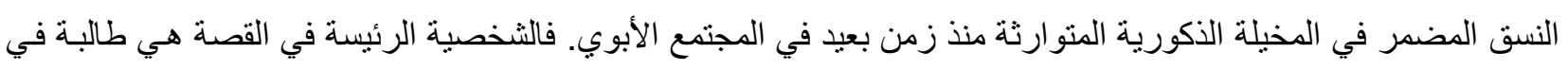

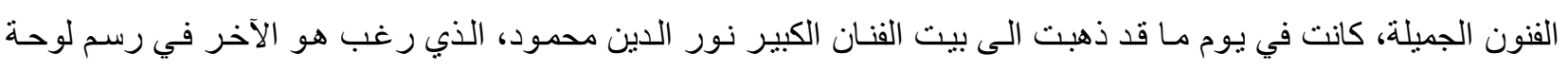

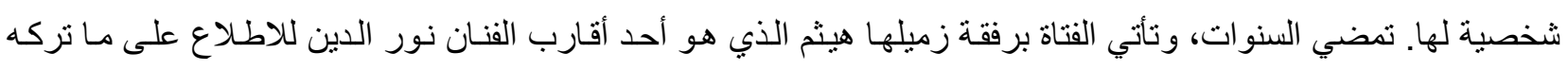

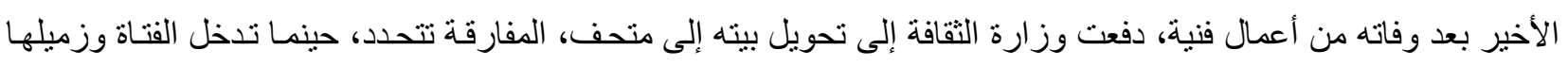


غرفة نوم الفنان، فتتفاجأ حينما تثاهد نفسها في اللوحة التي رسمها لها عارية من ثيابها تمامـاً، مما يصيبها بالفزع و الغضب:

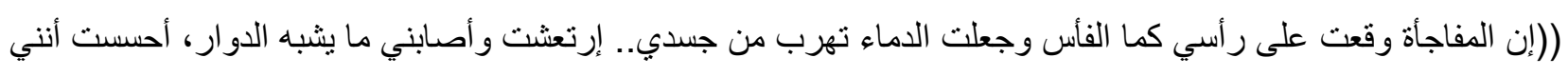

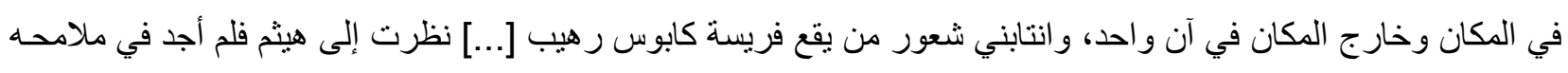

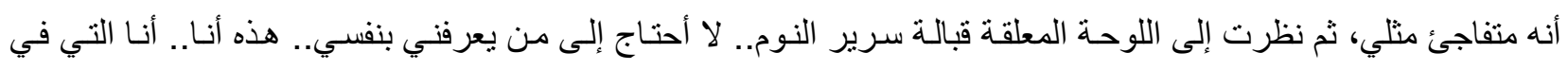

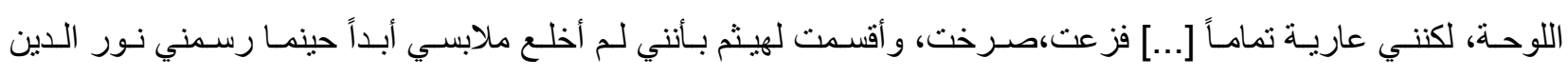

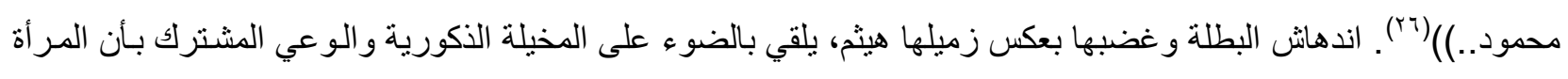

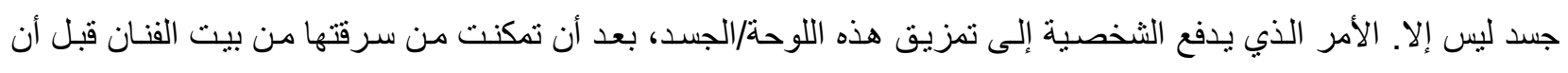

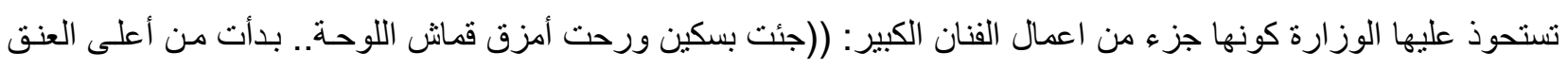

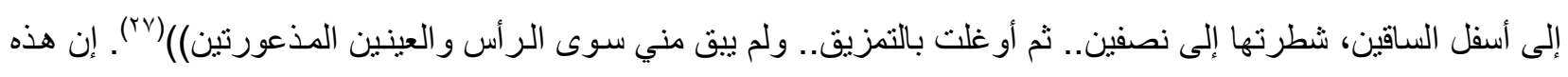

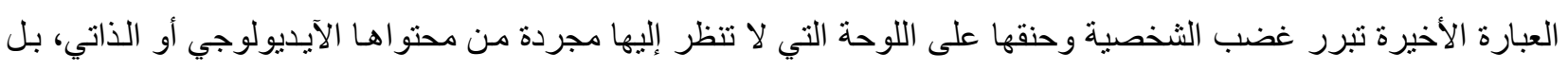

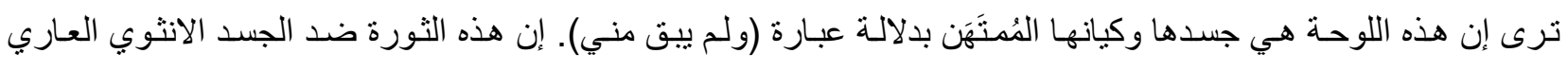

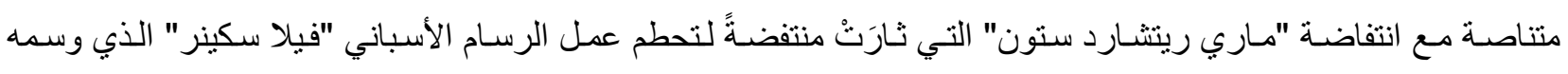

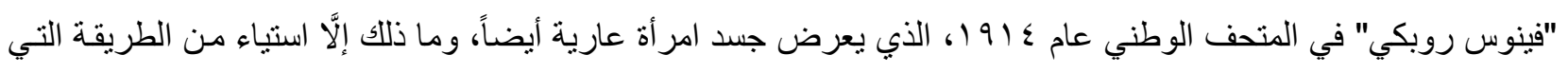

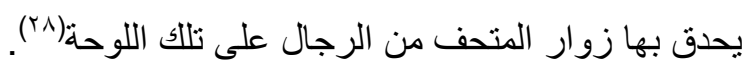

أما المفارقة في قصة (مخبول) فتتحدد في شخصية المخبول الذب ما ان يثاهده الأطفال و أصحاب المحلات التجاريـة

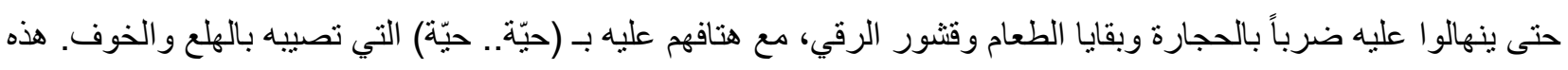

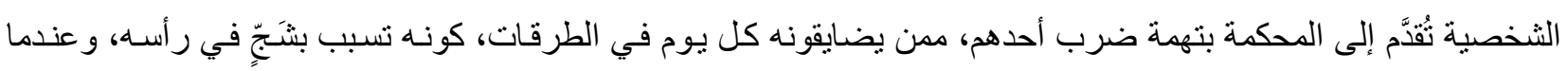

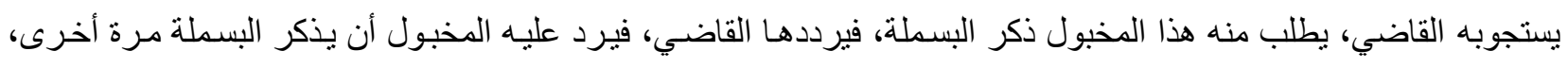

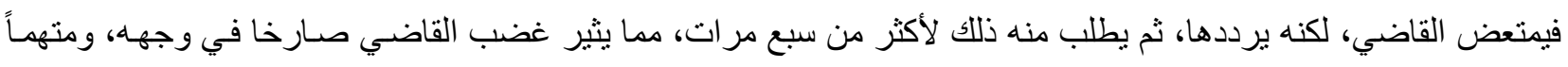

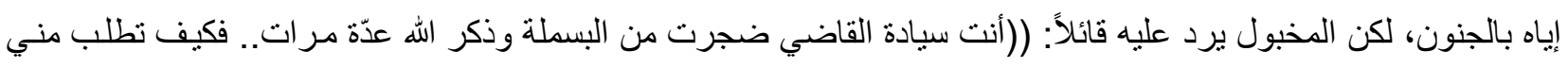
التعقل و أنا أتلقى الضرب، لكن السمع التخويف آلاف المرات... أصدر الحاج علوان صوناً طرقت تلابيبه مسامع القاضي..

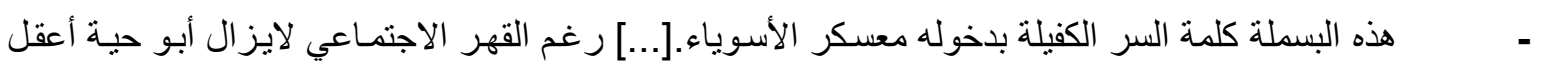

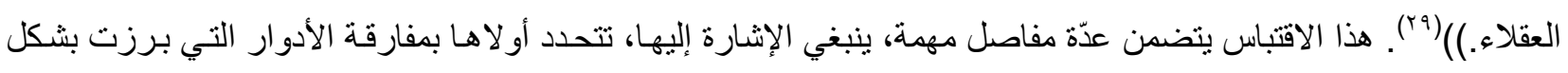

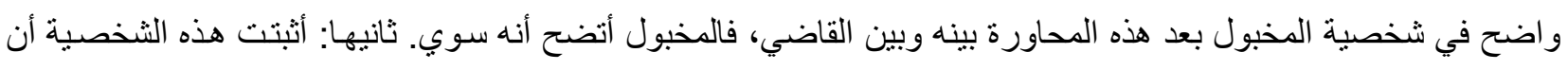

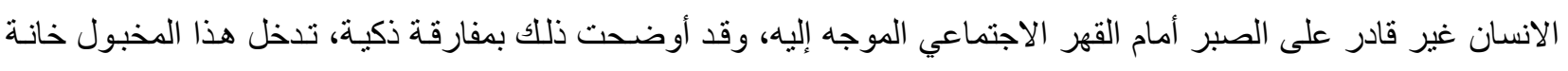

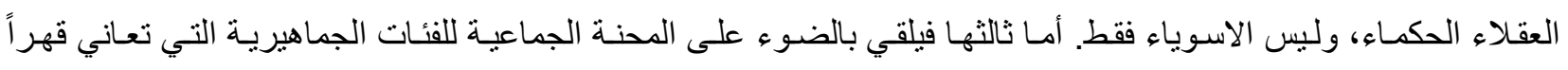

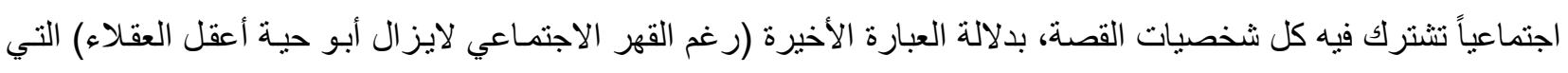

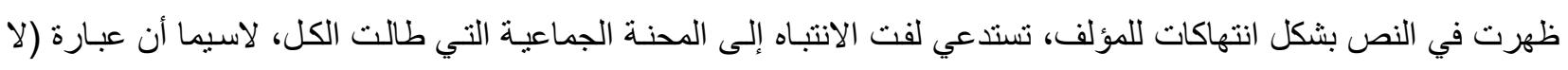

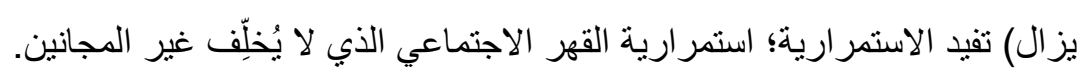

\section{ثالثآ: هفارقة بداية:}

يمكن عد البداية بأنها بنيـة استهلالية لها أهمية كبيرة في أي نص أدبي، تكمن تلك الأهمية في وظيفتها التشويقية

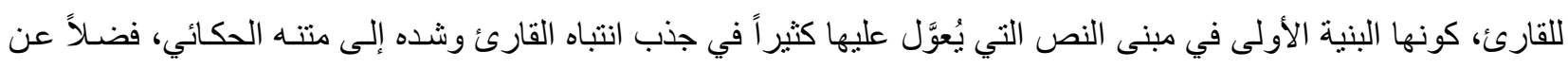

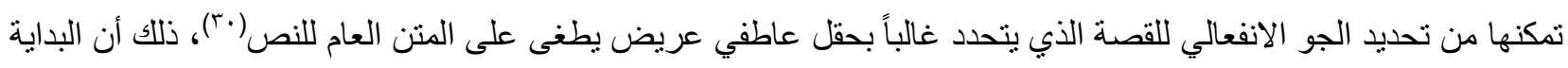




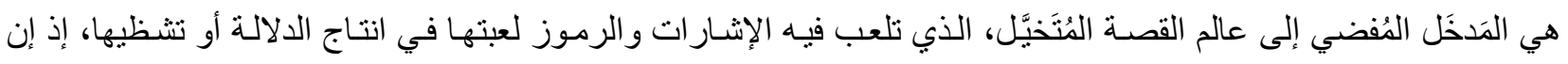

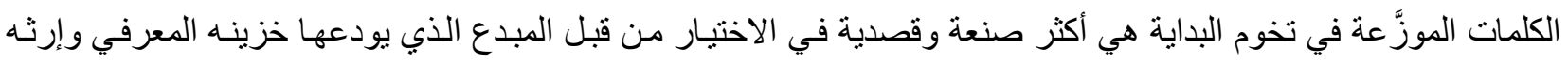

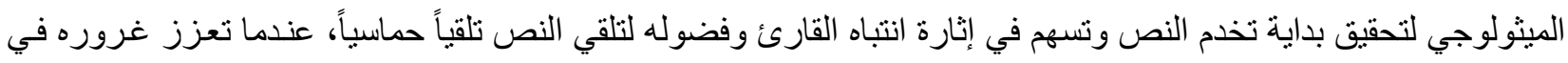

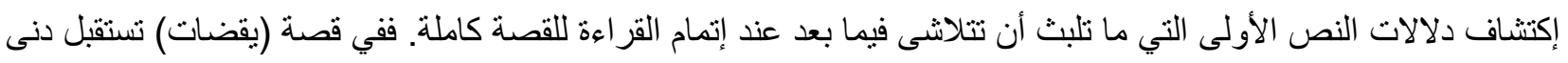

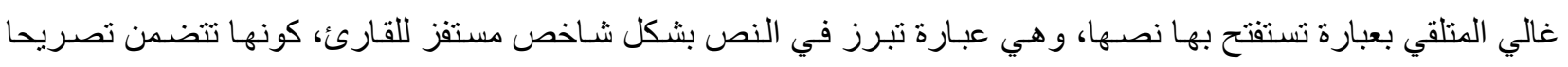

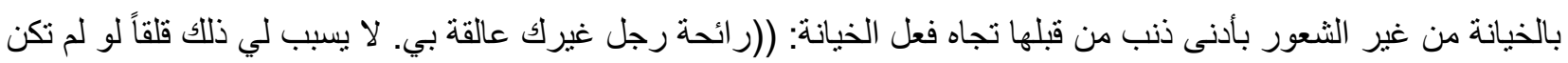

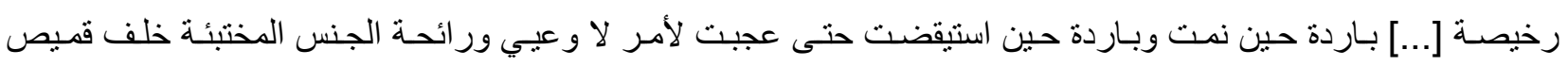

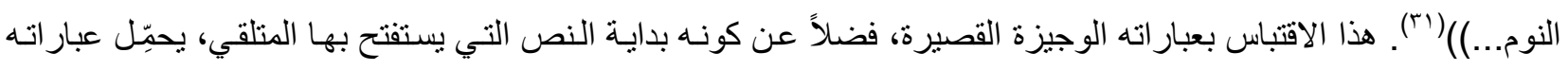

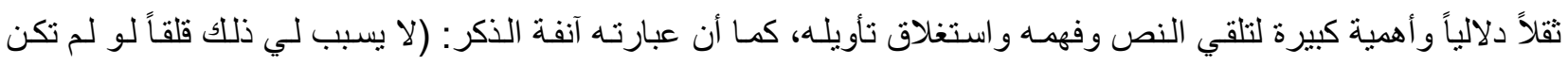

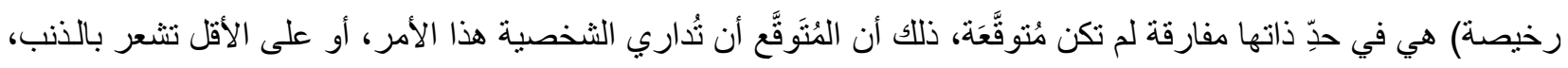

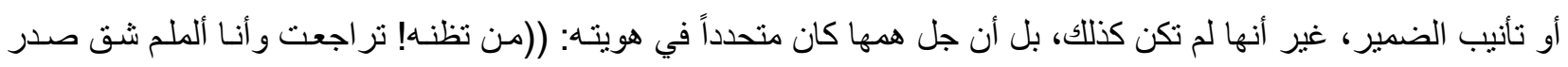

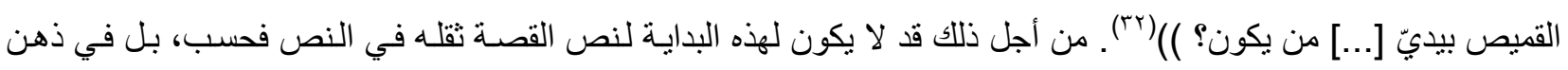

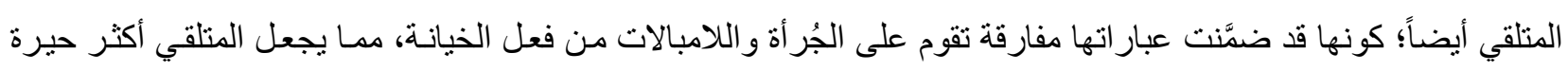

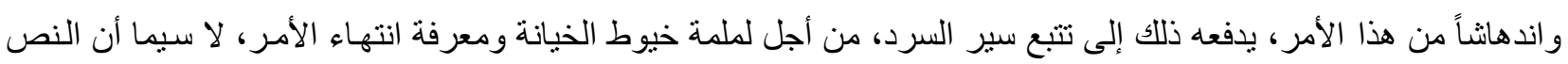

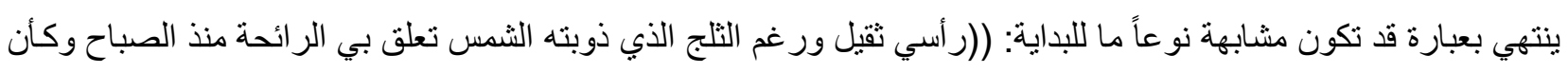

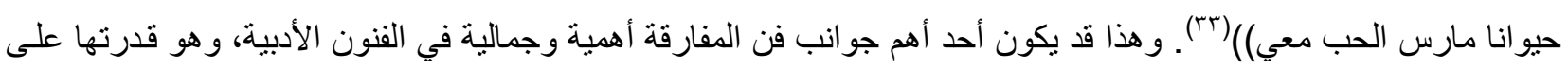

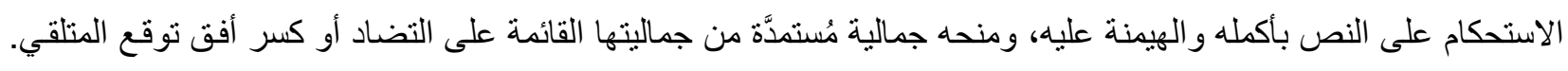

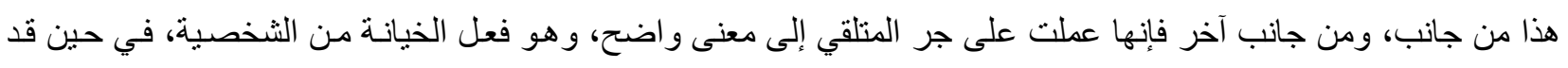

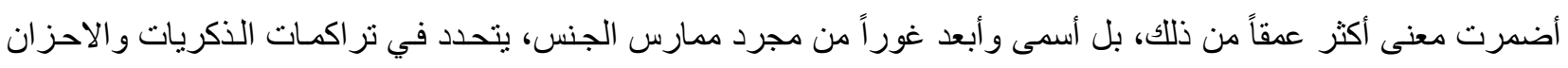

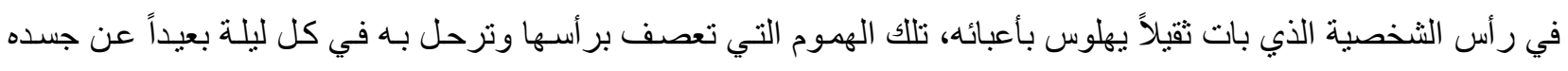

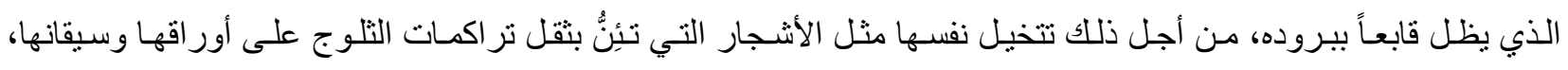

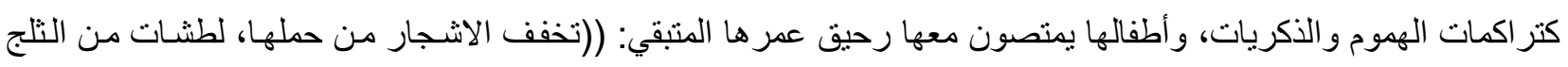

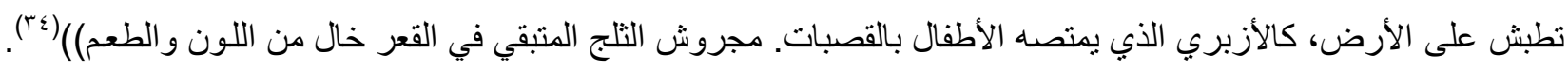

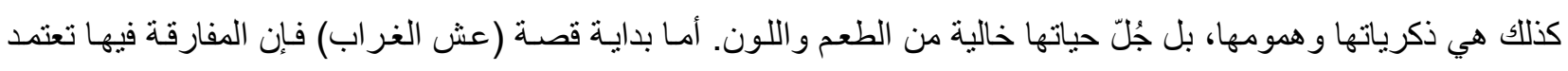

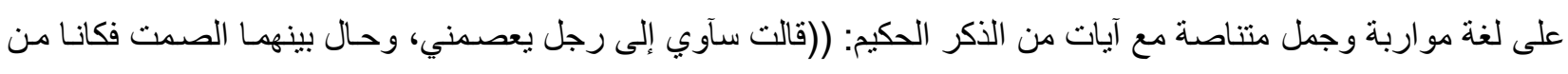

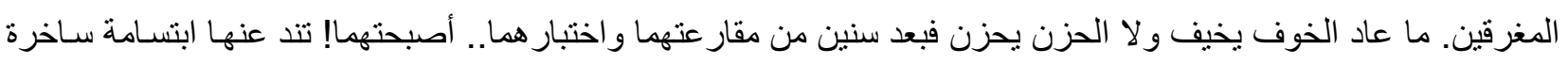

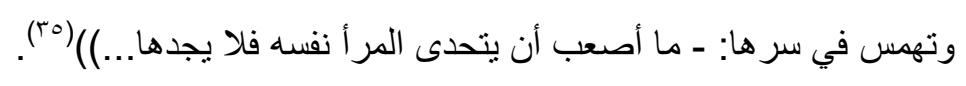

تبني هذه البداية بجملها المرصوفة رصفاً مفارقة تقوم مفاهيمها المتشظية على مداليل قصـة نوح (عله السلام) الذي حال

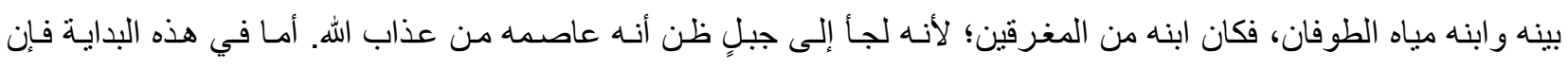

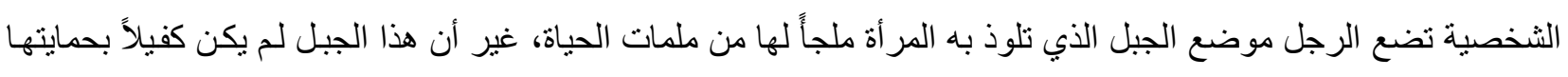

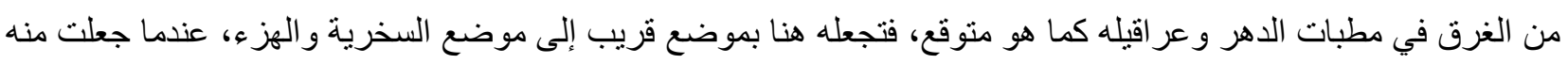

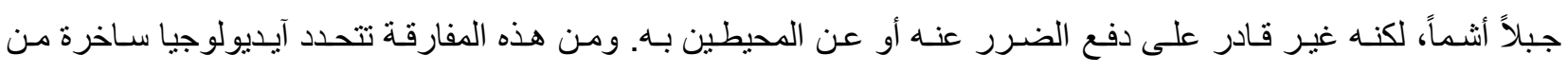

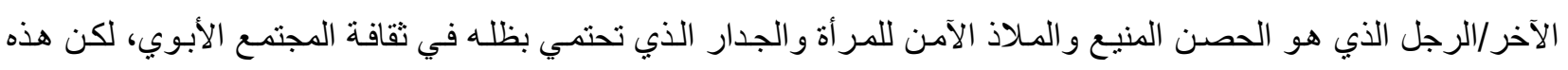

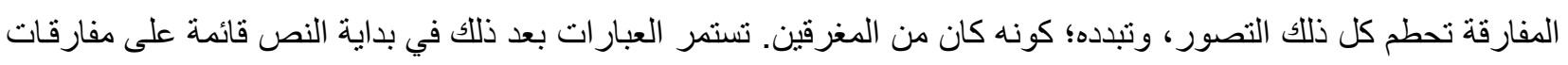

\section{-rrq.}


بجمل منضادة فيما بينها: (الخوف لا يخيف، الحزن لايحزن، تتحدى نفسها فلا تجدها) فكلها مفارقات تعتمد لغة مواربة توحي

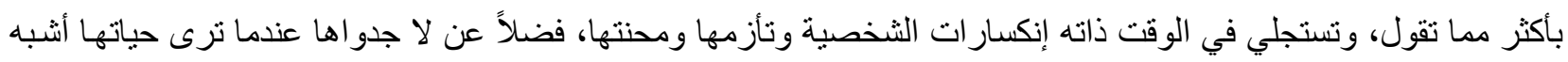

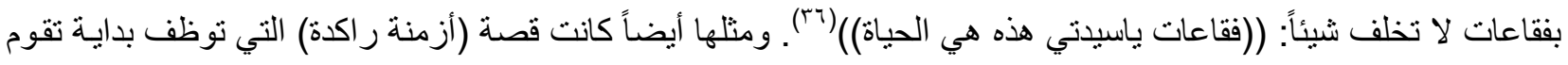
على مفارقة واضحة تربط بين حركة سمكة الزينة في الزجاجة الكرويـة، وطريقة عيش هذه البطلة: ((مسـار اتها كلها منحنية

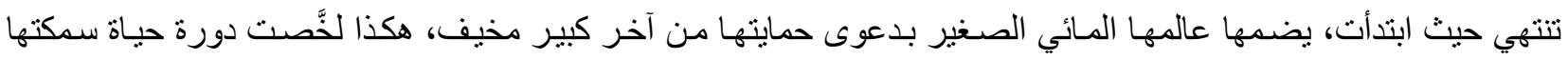

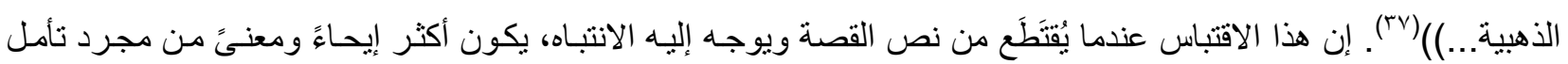

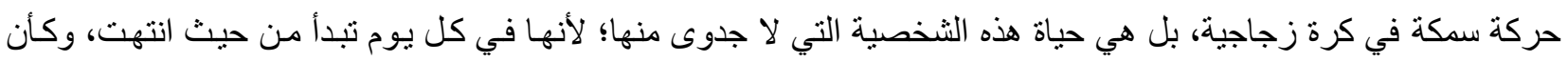

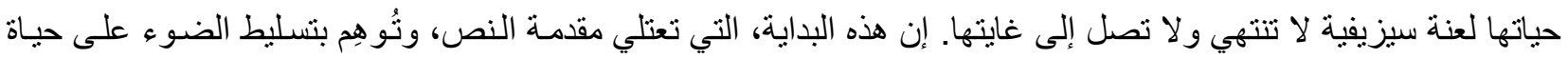

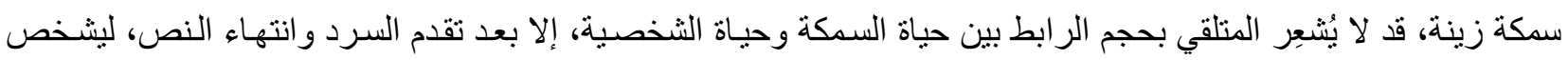

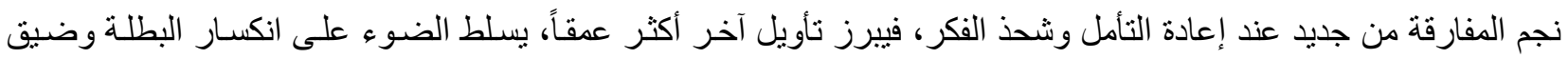

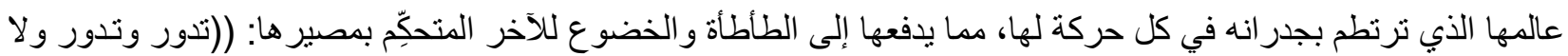

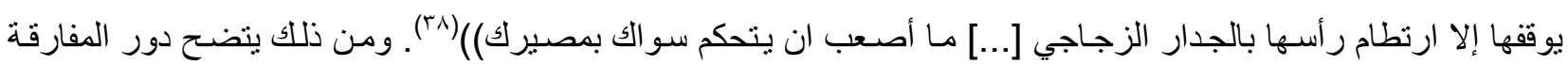

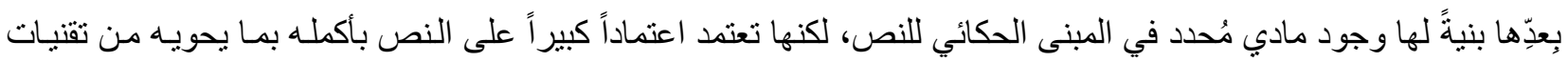

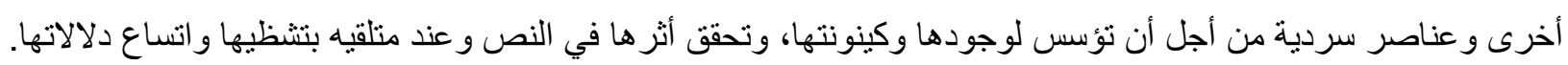

\section{رابعاً: هفارقة عنوان:}

تُعد العنو انات نصوصاً موازيةً لها دلالاتها ووظائفها التي تَصُب في خدمة النص الأصل وإغناء تأويلاته وشحذها(ب9)،

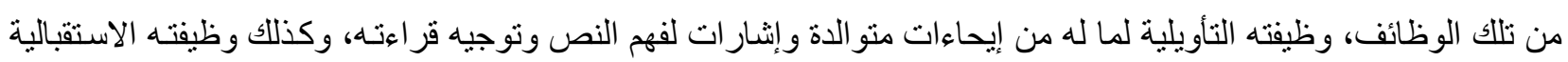

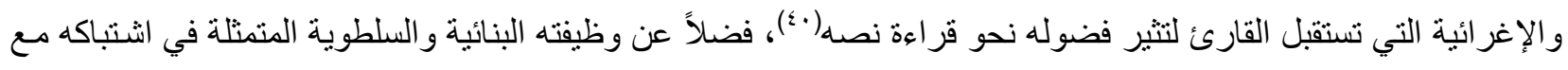
عناصر النص من أجل انتاج الدلالة المنشودة، هذا في الوقت الذي كان يعاني فيه العنوان إهمالاً و اضحاً في الدر اسـات النقديـة

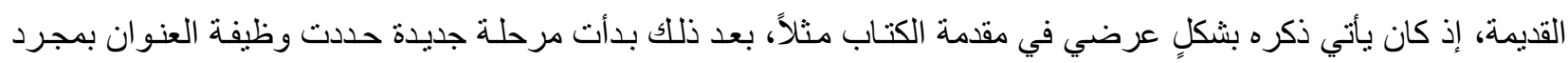

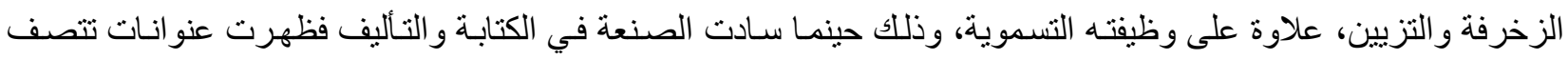

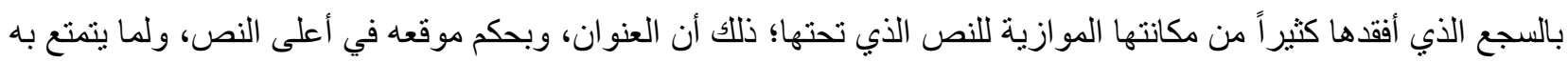

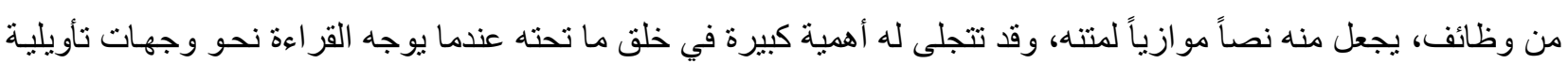

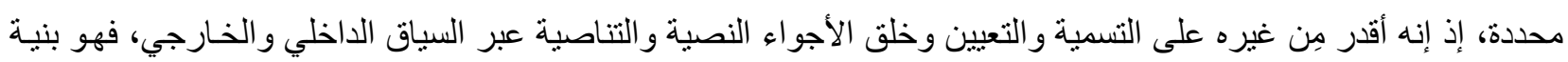

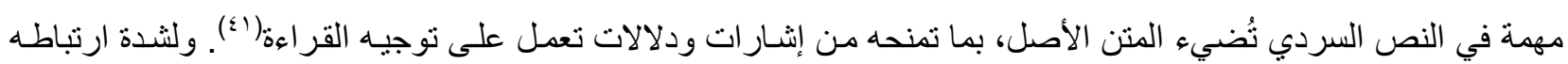

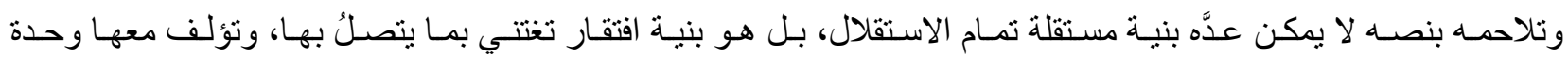

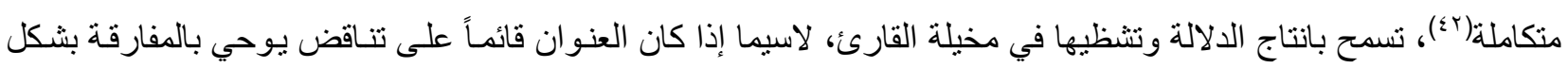

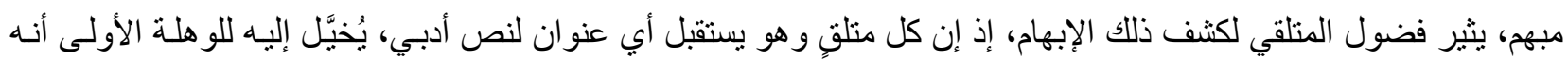

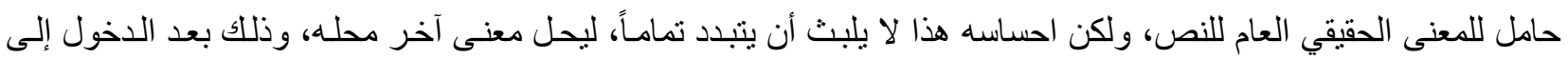

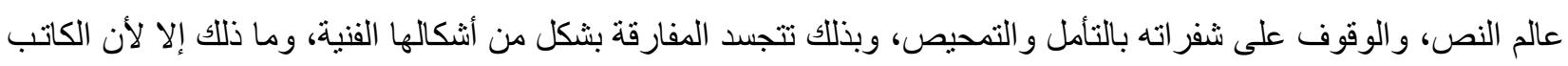

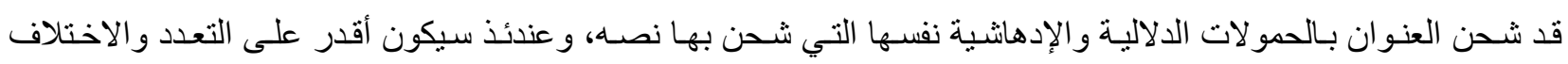

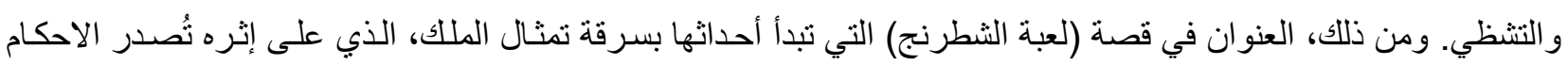

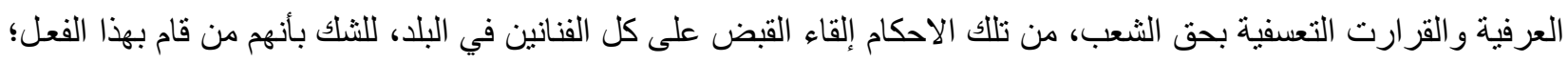

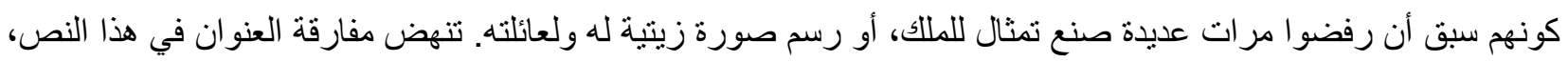


عندما يتبدد الغوض عن دلالته بأن لعبة الثطرنج، هي اللعبة المفضيَّلة لهؤلاء الفنانين السجناء، يلعبونها بأسنانهم التي اقتلعت بسبب التعذيب، أو بسبب التهاب اللثة الذي اصساب فكوكهم، بسبب الاهمال لها في السجن: ((شر عنا نلعب الثطرنج بأسناننا و أضر اسنا، بعد أن حرمنا من زيارة أطباء الاسنان[...] تحولت زنزانات السجن الى قاعات للعب الثطرنج.. كانت المباريات

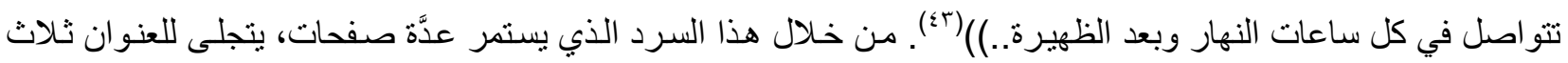

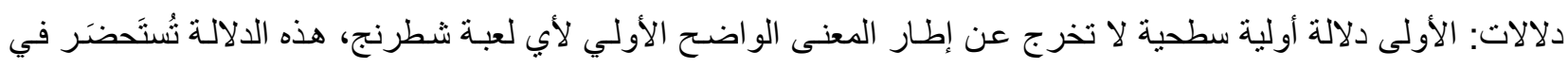

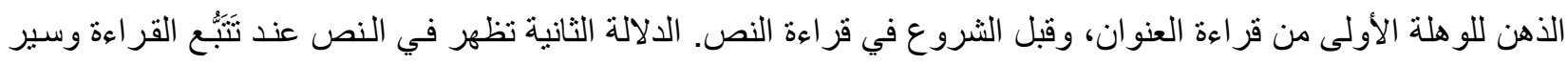

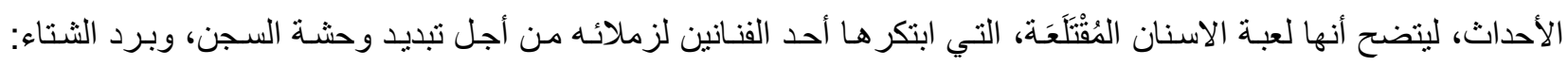

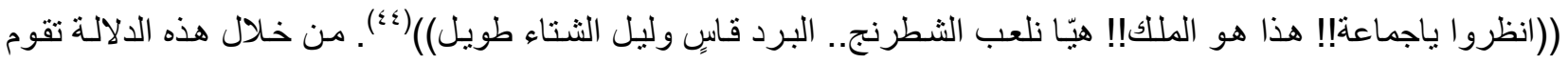

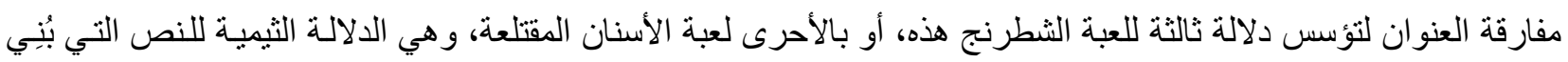

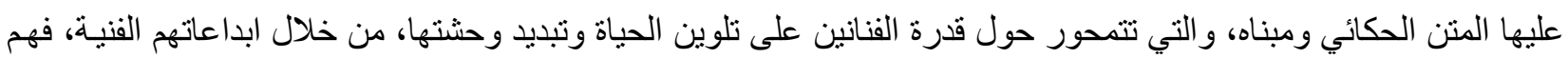

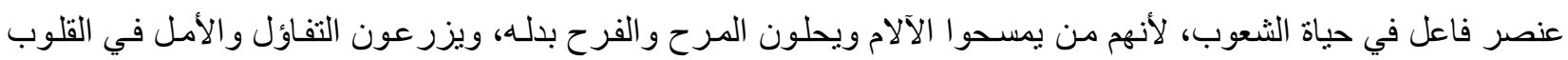

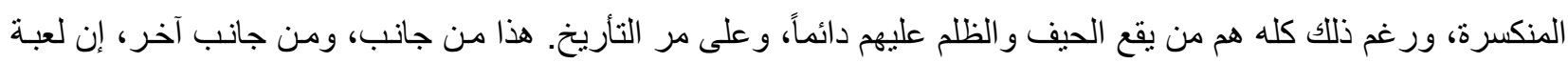

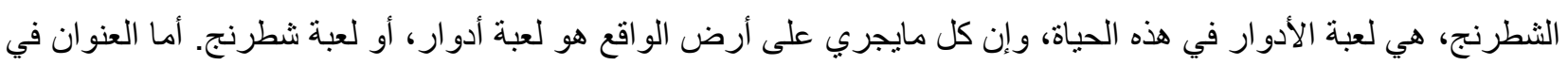

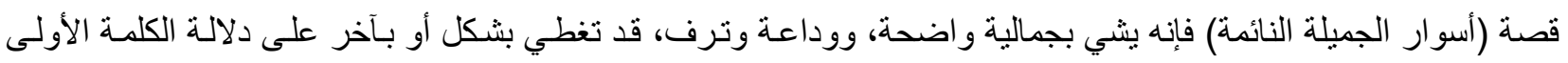

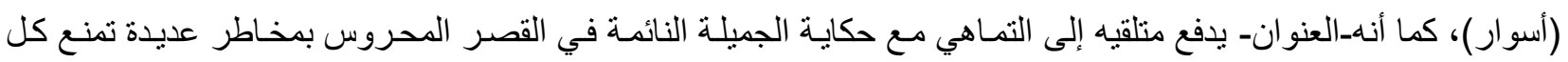

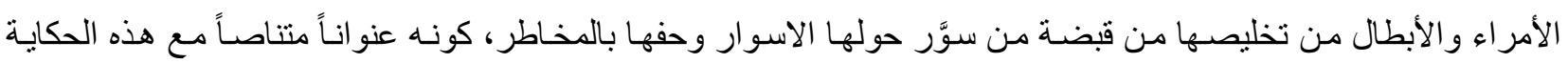

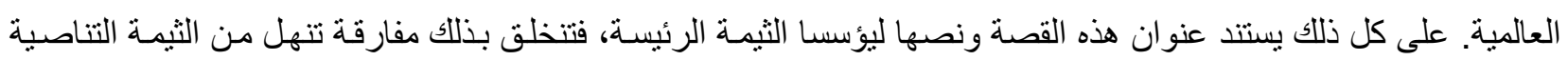

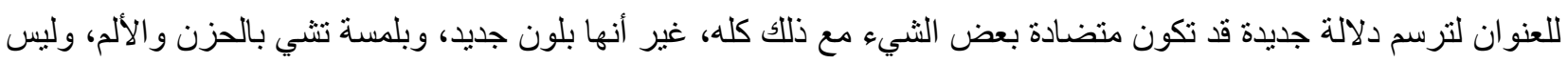

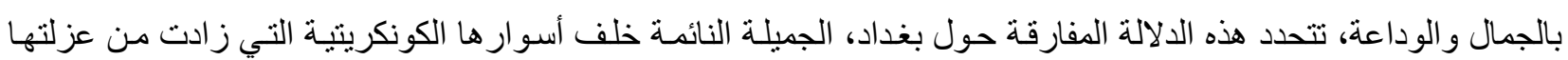

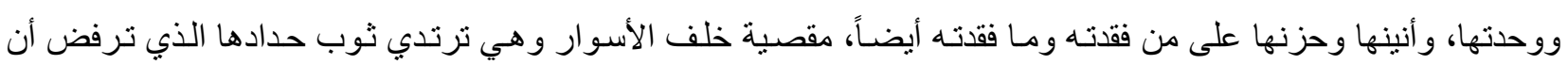

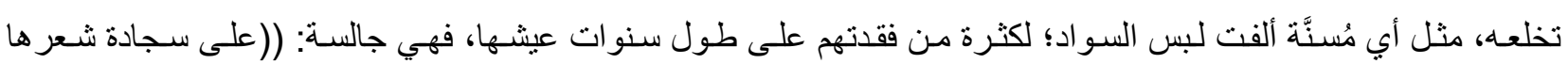

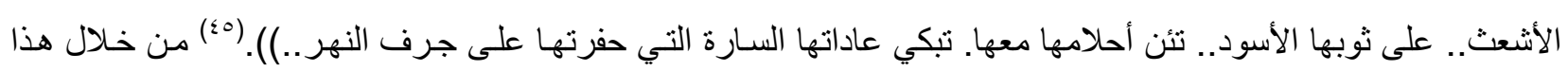

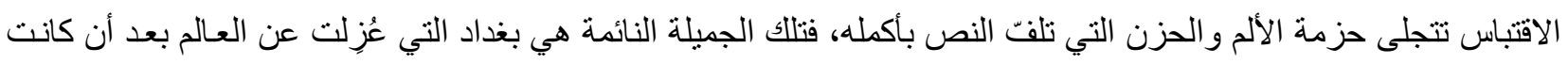

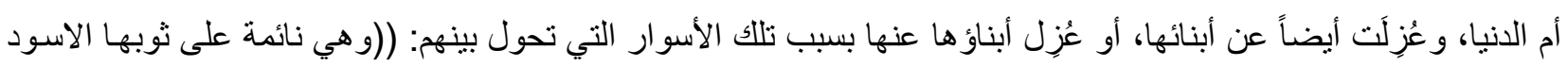

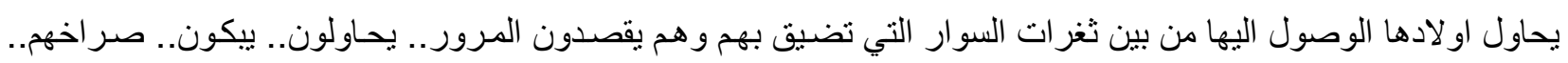

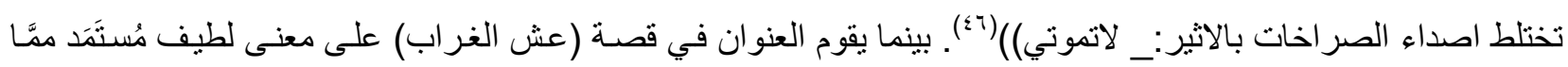

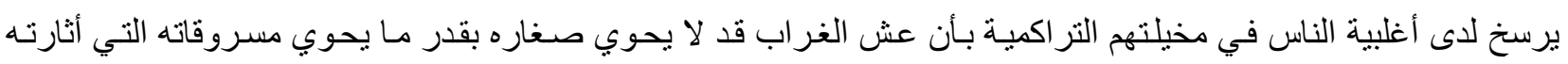

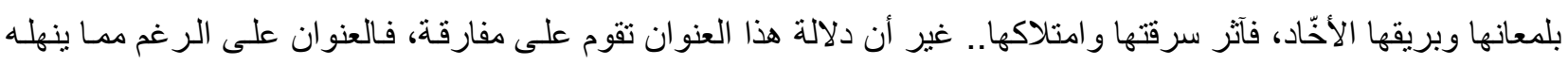

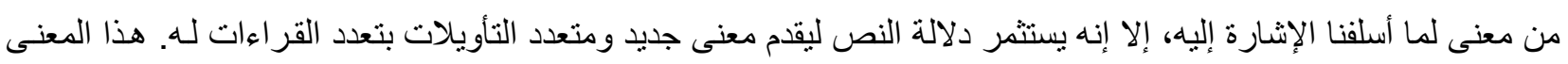

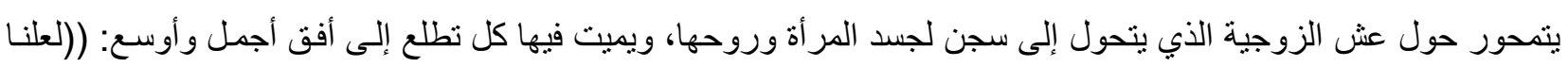

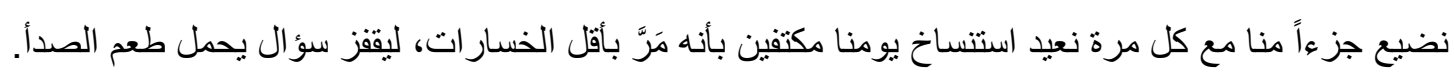

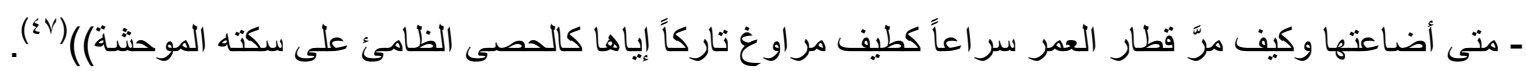

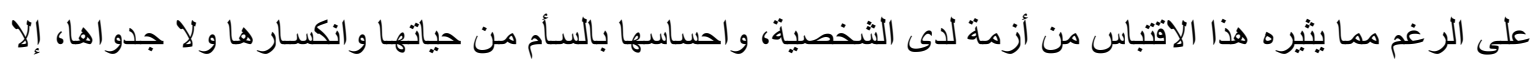

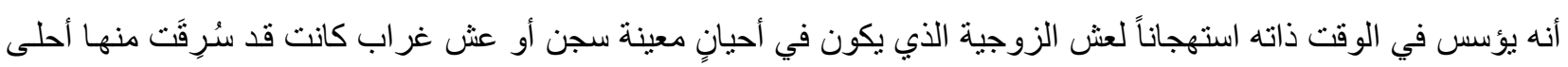


أيامها وهي في ذلك العش، بعد أن سُرِقَت هي لتوضع فيه. من ذلك يتضح ما للعنوان من إنساع دلالي يجعل منـه نصـاً موازياً

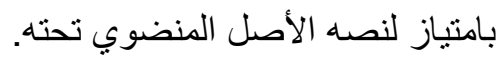

أثنتت النصوص السردية عينة البحث أن المفارقة مفصل شديد التلاحم مع كل عناصر النص وأجزائه التي تعمل ككل

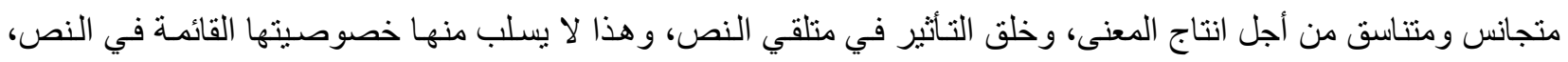

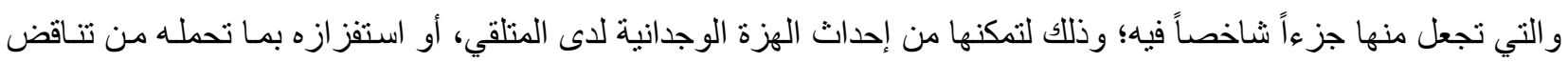

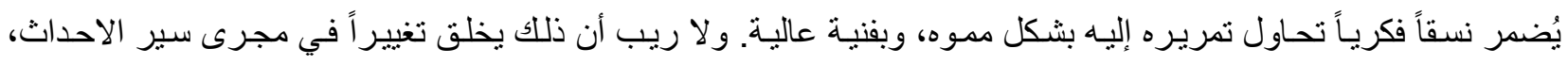

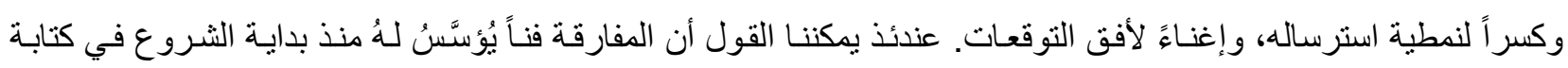

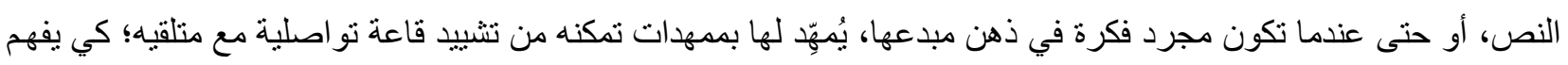

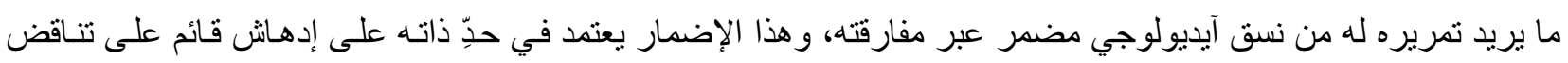

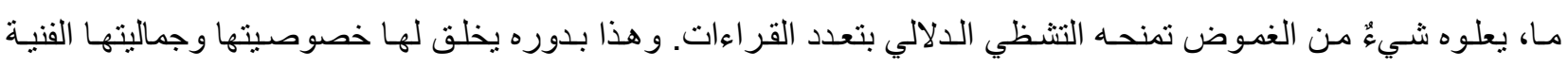

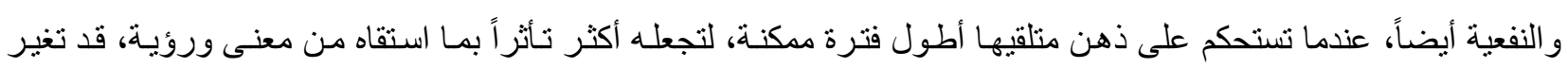

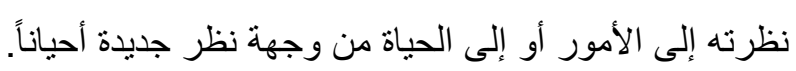

هواهش البحث

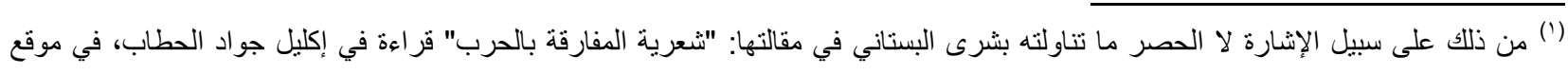

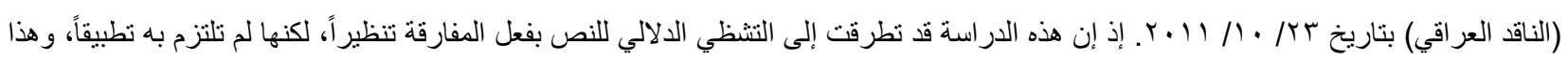

حال العديد من الدراسات التي أهتمت بالمفارقة.

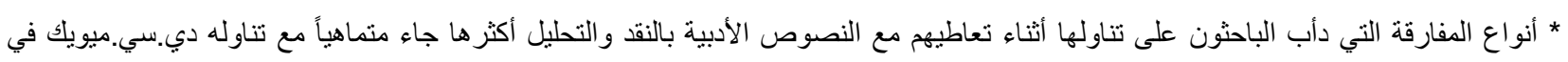

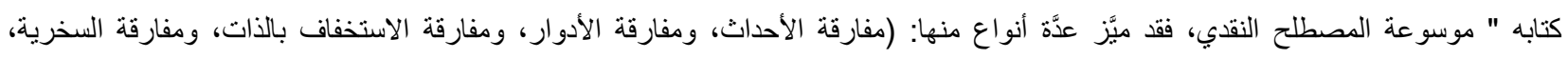

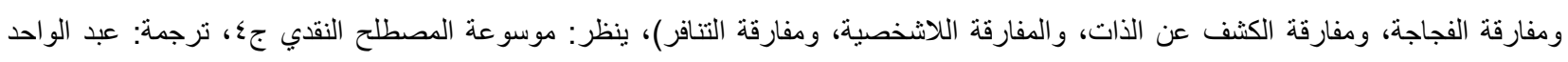

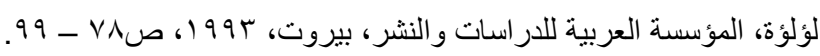

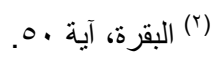

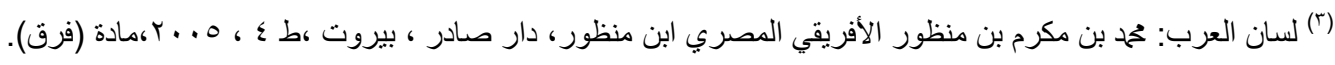

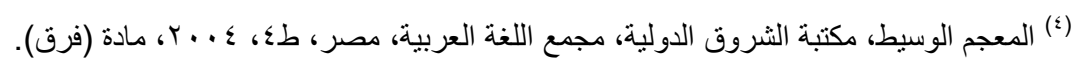

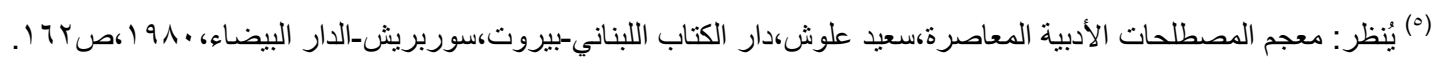

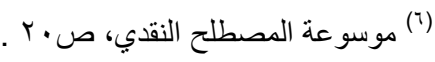

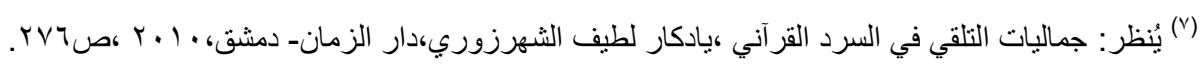

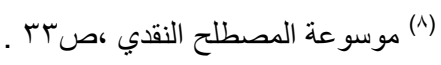

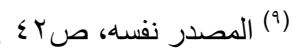

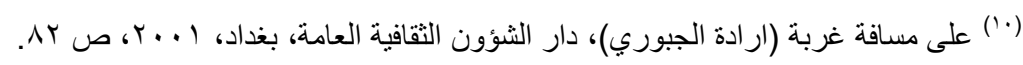

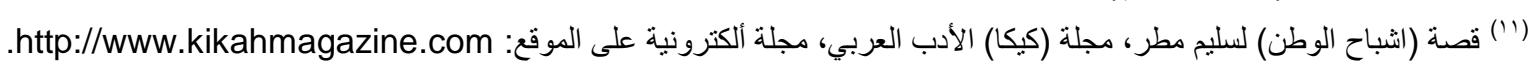
(r) (r) (') المصدر نفسه، الصفحة نفسها.

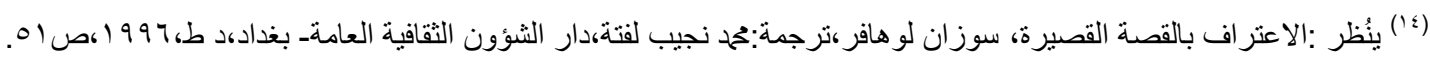
(10) ينُطر: البناء الفني للقصة القصيرة (القصة العراقية نموذجاً) "اطروحة دكتور اه"،مطبوعة على الآلة الكاتبة،ثائر عبد المجيبد العذاري،كلية

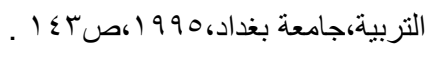

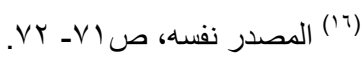
VYV (IV)

\section{- Mrr}




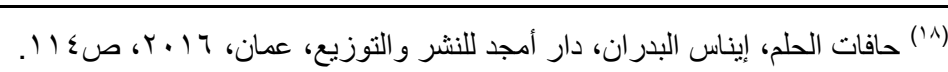

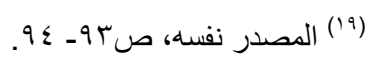

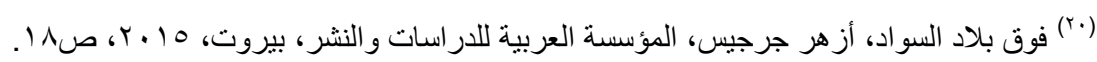

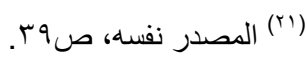

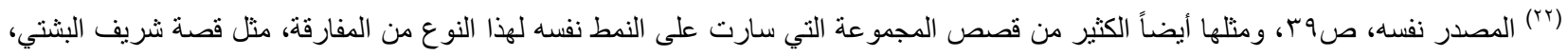
وقصة رقصة نوفا، وقصة سائق الجنائز ... وغير ها، وكذلك قصة (آخر رغيف) لعلي السباعي في مجمو عنه: إيقاعات الزمن الر اقص، منشور ات اتحاد

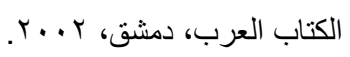

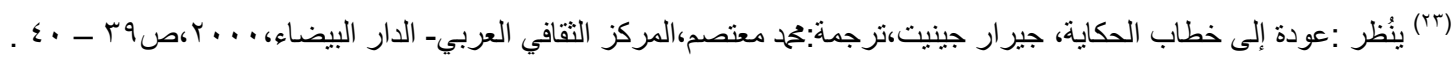

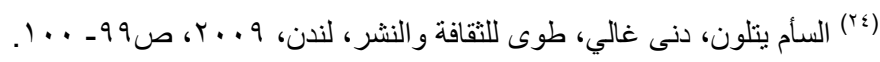

$$
\text { (1) (10) }
$$

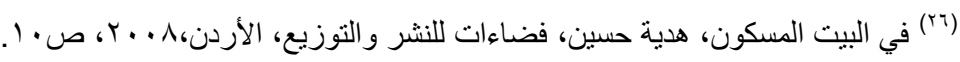

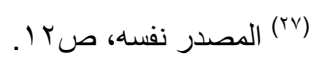

(r^) بنظر: النسوية وما بعد النسوية، سارة جامبل، نرجمة: أحمد الثامي،المشروع القومي للترجمة، المجلس الأعلى للثقافة، الهيئة العامة لثؤون المطابع

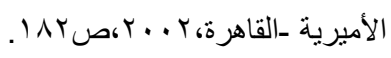

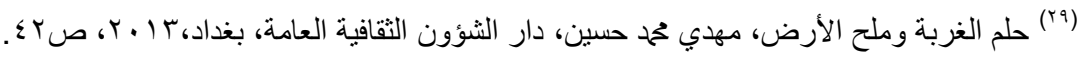

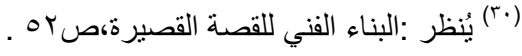

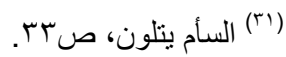

$$
\begin{aligned}
& \text { ( المصدر نفسه، ص سب (Tr) }
\end{aligned}
$$

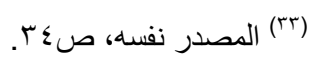

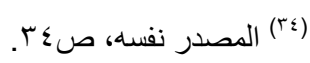

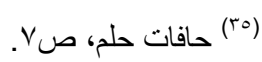

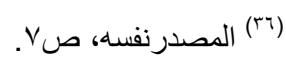

$$
\begin{aligned}
& \text { ( المصدر نفسه، }
\end{aligned}
$$

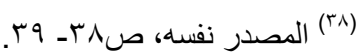

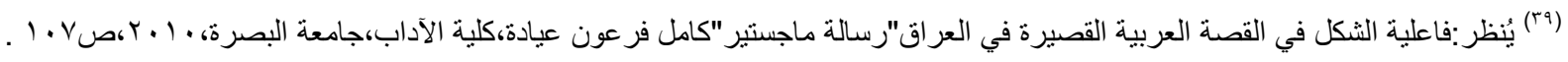

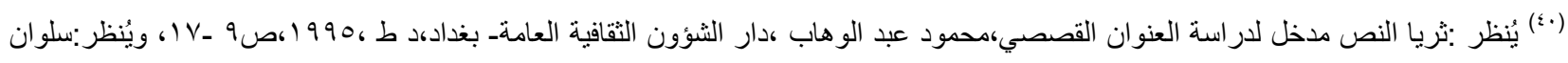

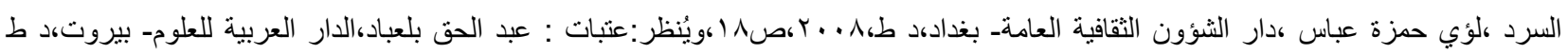

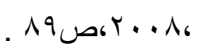

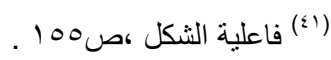

.

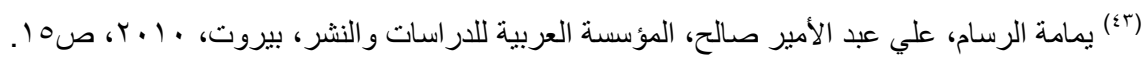

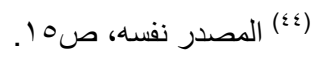

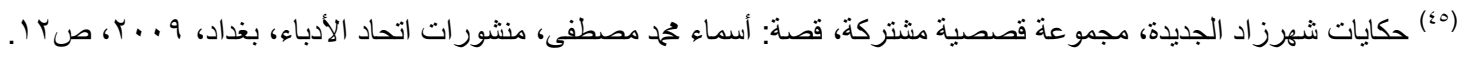

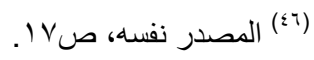

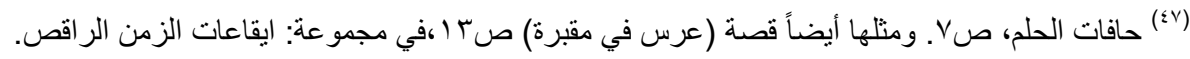




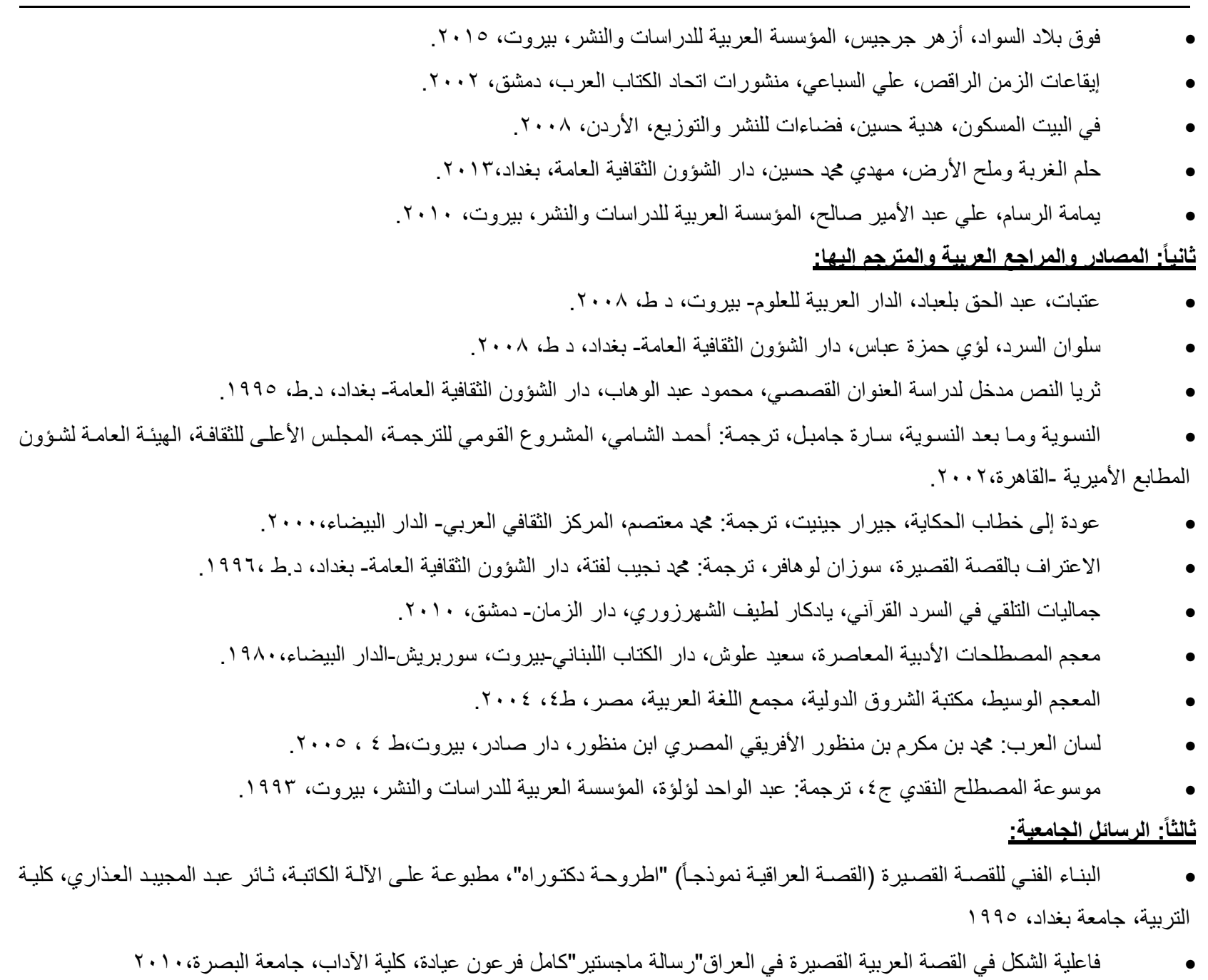

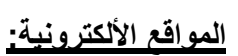

http://www.kikahmagazine.com مجلة (كيكا) الأدب العربي، قصة (اشباح الوطن) لسليم مطر ، مجلة أكترونية على الموقع:

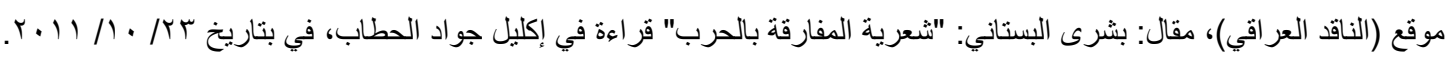

